Atmos. Chem. Phys., 18, 11261-11275, 2018

https://doi.org/10.5194/acp-18-11261-2018

(C) Author(s) 2018. This work is distributed under

the Creative Commons Attribution 4.0 License.

\title{
Summertime fine particulate nitrate pollution in the North China Plain: increasing trends, formation mechanisms and implications for control policy
}

\author{
Liang Wen ${ }^{1}$, Likun Xue $^{1}$, Xinfeng Wang ${ }^{1}$, Caihong Xu ${ }^{1}$, Tianshu Chen ${ }^{1}$, Lingxiao Yang ${ }^{1}$, Tao Wang ${ }^{2}$, \\ Qingzhu Zhang ${ }^{1}$, and Wenxing Wang ${ }^{1}$ \\ ${ }^{1}$ Environment Research Institute, Shandong University, Jinan, Shandong, China \\ ${ }^{2}$ Department of Civil and Environmental Engineering, Hong Kong Polytechnic University, Hong Kong, China
}

Correspondence: Likun Xue (xuelikun@sdu.edu.cn)

Received: 31 January 2018 - Discussion started: 8 February 2018

Revised: 18 July 2018 - Accepted: 23 July 2018 - Published: 13 August 2018

\begin{abstract}
Nitrate aerosol makes up a significant fraction of fine particles and plays a key role in regional air quality and climate. The North China Plain (NCP) is one of the most industrialized and polluted regions in China. To obtain a holistic understanding of the nitrate pollution and its formation mechanisms over the NCP region, intensive field observations were conducted at three sites during summertime in 2014-2015. The measurement sites include an urban site in downtown Jinan - the capital city of Shandong Province -, a rural site downwind of Jinan city, and a remote mountain site at Mt. Tai (1534 ma.s.l.). Elevated nitrate concentrations were observed at all three sites despite distinct temporal and spatial variations. Using historical observations, the nitrate / $\mathrm{PM}_{2.5}$ and nitrate / sulfate ratios have statistically significantly increased in Jinan (2005-2015) and at Mt. Tai (from 2007 to 2014), indicating the worsening situation of regional nitrate pollution. A multiphase chemical box model (RACM-CAPRAM) was deployed and constrained by observations to elucidate the nitrate formation mechanisms. The principal formation route is the partitioning of gaseous $\mathrm{HNO}_{3}$ to the aerosol phase during the day, whilst the nocturnal nitrate formation is dominated by the heterogeneous hydrolysis of $\mathrm{N}_{2} \mathrm{O}_{5}$. The daytime nitrate production in the NCP region is mainly limited by the availability of $\mathrm{NO}_{2}$ and to a lesser extent by $\mathrm{O}_{3}$ and $\mathrm{NH}_{3}$. In comparison, the nighttime formation is controlled by both $\mathrm{NO}_{2}$ and $\mathrm{O}_{3}$. The presence of $\mathrm{NH}_{3}$ contributes to the formation of nitrate aerosol during the day, while there is slightly decreasing nitrate formation at night. Our analyses suggest that controlling $\mathrm{NO}_{x}$ and $\mathrm{O}_{3}$ is an efficient way, at the moment,
\end{abstract}

to mitigate nitrate pollution in the NCP region, where $\mathrm{NH}_{3}$ is usually in excess in summer. This study provides observational evidence of a rising trend of nitrate aerosol as well as scientific support for formulating effective control strategies for regional haze in China.

\section{Introduction}

Atmospheric particles are vital players in tropospheric chemistry, regional air pollution and climate change. High concentrations of fine particles (i.e., $\mathrm{PM}_{2.5}$ ) can reduce visibility (Xu and Penner, 2012), deteriorate air quality (Huang et al., 2014) and are harmful to human health (Xie et al., 2016). They play an essential role in Earth's radiation balance and hence affect climate change, directly by scattering and absorbing the incoming solar radiation (IPCC, 2013) and indirectly by modifying the cloud properties (Ding et al., 2013; Fukushima et al., 2016). Aerosol particles can also serve as a medium for reactive gases to undergo heterogeneous and aqueous-phase reactions (Chang et al., 2011). Understanding the chemical composition and sources of atmospheric particles is crucial for quantifying their environmental and health consequences and formulating science-based mitigation strategies.

Particulate nitrate $\left(\mathrm{NO}_{3}^{-}\right)$is a principal chemical component of atmospheric fine particles. It is an oxidation product of nitrogen oxides $\left(\mathrm{NO}_{x}=\mathrm{NO}+\mathrm{NO}_{2}\right)$ in the ambient atmosphere. During the day, the oxidation of $\mathrm{NO}_{2}$ by the hy- 
droxyl radical $(\mathrm{OH})$ produces gaseous nitric acid $\left(\mathrm{HNO}_{3}\right)$, which then reacts with ammonia $\left(\mathrm{NH}_{3}\right)$ or other alkaline compounds to form nitrate aerosol (Calvert and Stockwell, 1983). The partitioning of $\mathrm{HNO}_{3}$ between gas and aerosol phases is dependent on ambient temperature, humidity and the abundances of alkaline species (Song and Carmichael, 2001; X. Wang et al., 2009; Yao and Zhang, 2012). In dark conditions, the reaction of $\mathrm{NO}_{2}$ and $\mathrm{O}_{3}$ produces the nitrate radical $\left(\mathrm{NO}_{3}\right)$, which forms an equilibrium with $\mathrm{N}_{2} \mathrm{O}_{5}$ that can be subsequently taken up onto particles to enhance nitrate aerosol (Pathak et al., 2009, 2011; Brown and Stutz, 2012). The contribution from this pathway is minimized during the day by the rapid photolysis of $\mathrm{NO}_{3}$ and thermal decomposition of $\mathrm{N}_{2} \mathrm{O}_{5}$. The $\mathrm{HNO}_{3}$ partitioning and $\mathrm{N}_{2} \mathrm{O}_{5}$ hydrolysis reactions have been recognized as the major sink pathways of $\mathrm{NO}_{x}$ in the troposphere (Dentener and Crutzen, 1993; Liu et al., 2013). There are some other formation routes of nitrate aerosol, such as the uptake of $\mathrm{NO}_{3}$ radicals onto particles and their subsequent aqueous reactions with some water-soluble species (Hallquist et al., 1999; see also Table S1 in the Supplement). The ambient formation of nitrate aerosol highly depends on the chemical mix of $\mathrm{NO}_{x}$, $\mathrm{O}_{3}$ and $\mathrm{NH}_{3}$. To date the detailed relationship between nitrate formation and the chemical mix of $\mathrm{NO}_{x}, \mathrm{O}_{3}$ and $\mathrm{NH}_{3}$ is still poorly understood. The contribution of the $\mathrm{N}_{2} \mathrm{O}_{5}$ hydrolysis pathway tends to show a seasonal dependence on the largest influence in the winter season (Brown and Stutz, 2012; Baasandorj et al., 2017) but will be dependent on the rate of $\mathrm{NO}_{3}$ formation and reaction, the $\mathrm{N}_{2} \mathrm{O}_{5}$ uptake coefficient $\left(\gamma\left(\mathrm{N}_{2} \mathrm{O}_{5}\right)\right)$ and formation yield of $\mathrm{ClNO}_{2}$. Field measurement studies have shown that the $\gamma\left(\mathrm{N}_{2} \mathrm{O}_{5}\right)$ is highly variable and disagrees with the laboratory-derived parameterizations (Brown and Stutz, 2012; McDuffie et al., 2018; Tham et al., 2018). Vertical mixing of air aloft in the residual layer may also contribute to the surface nitrate pollution (Watson et al., 2002; Brown et al., 2006; Pusede et al., 2016; Baasanforj et al., 2017; Prabhakar et al., 2017). Consequently, there are still some remaining questions for better understanding the nitrate formation mechanisms.

China has been suffering from severe haze pollution as a result of its fast urbanization and industrialization processes in the past decades. The North China Plain (NCP), covering the Beijing-Tianjin-Hebei area and surrounding Shandong and Henan provinces, is the most polluted region with the highest annual concentrations of $\mathrm{PM}_{2.5}$ in China (http://www.cnemc.cn/kqzlzkbgyb2092938.jhtml). Previous air pollution control in China primarily focused on the reduction in anthropogenic emissions of sulfur dioxide $\left(\mathrm{SO}_{2}\right)$, given the dominant contributions of sulfate $\left(\mathrm{SO}_{4}^{2-}\right)$ to the $\mathrm{PM}_{2.5}$ and acid deposition (Hao et al., 2000, 2007). In the last decade, a circa $75 \%$ reduction in $\mathrm{SO}_{2}$ emissions in China has successfully resulted in decreases in the ambient levels of both $\mathrm{SO}_{2}$ and aerosol $\mathrm{SO}_{4}^{2-}$ in fast-developing regions including the NCP (Wang et al., 2013; Li et al., 2017). In comparison, several recent observational studies have indicated an increasingly important role of aerosol nitrate, which may even dominate summertime haze formation in the NCP region (Wen et al., 2015; Li et al., 2018). A recent modeling study has predicted a significant increase in aerosol nitrate along with the decrease in sulfate during 2006-2015 over eastern China (Wang et al., 2013). To the best of our knowledge, there are no previous observational reports of increasing nitrate aerosol over northern China. Long-term measurements are necessary to confirm and quantify this trend and better understand the nitrate formation mechanisms in China.

To achieve a better understanding of the summertime nitrate pollution and its formation mechanism in the NCP region, four phases of intensive observations were conducted at three different sites covering urban, rural and remote areas in 2014 and 2015. The spatial distribution and temporal variation in nitrate aerosol pollution were examined. The data were combined with previous measurements to derive the trends of the nitrate / $\mathrm{PM}_{2.5}$ and nitrate / sulfate ratios, confirming the statistically significant increase in regional nitrate pollution during 2005-2015. A multiphase chemical box model, constrained by in situ observations, was then deployed to unravel the formation mechanisms of fine particulate nitrate. The impacts of $\mathrm{NO}_{2}, \mathrm{O}_{3}$ and $\mathrm{NH}_{3}$ on the regional nitrate formation were finally quantified. Overall, the present study provides the first piece of observational evidence for the increasing trend of nitrate aerosol in northern China, and our findings have important implications for the future control of regional haze pollution in the NCP region.

\section{Materials and methods}

\subsection{Study sites}

To better understand the regional-scale nitrate pollution and formation processes, four phases of intensive field campaigns were conducted at three sites in the central part of the North China Plain in the summers of 2014-2015. Considering that southerly/southeasterly winds generally prevail in summertime, the three study sites were carefully selected to lie on a southeast-northwest transect (see Fig. 1) and to represent the typical urban, rural and remote atmospheres of the region. A summary of the measurement locations and periods is shown in Table S2 in the Supplement.

The urban site $\left(36.67^{\circ} \mathrm{N}, 117.06^{\circ} \mathrm{E} ; \sim 50 \mathrm{~m}\right.$ above sea level, a.s.l.) was located in the downtown area of Jinan, the capital city of Shandong province, accommodating more than 7 million inhabitants, $\sim 1.7$ million automobiles and many factories. Jinan is one of the largest cities in the central NCP and has been frequently ranked among the worst ten key cities of China in terms of air quality (http://www.cnemc.cn/ kqzlzkbgyb2092938.jhtml). The site is built on the rooftop of a six-floor building in the Central Campus of Shandong University, which is situated in the residential and commercial areas. Details of this site have been provided in our previ- 

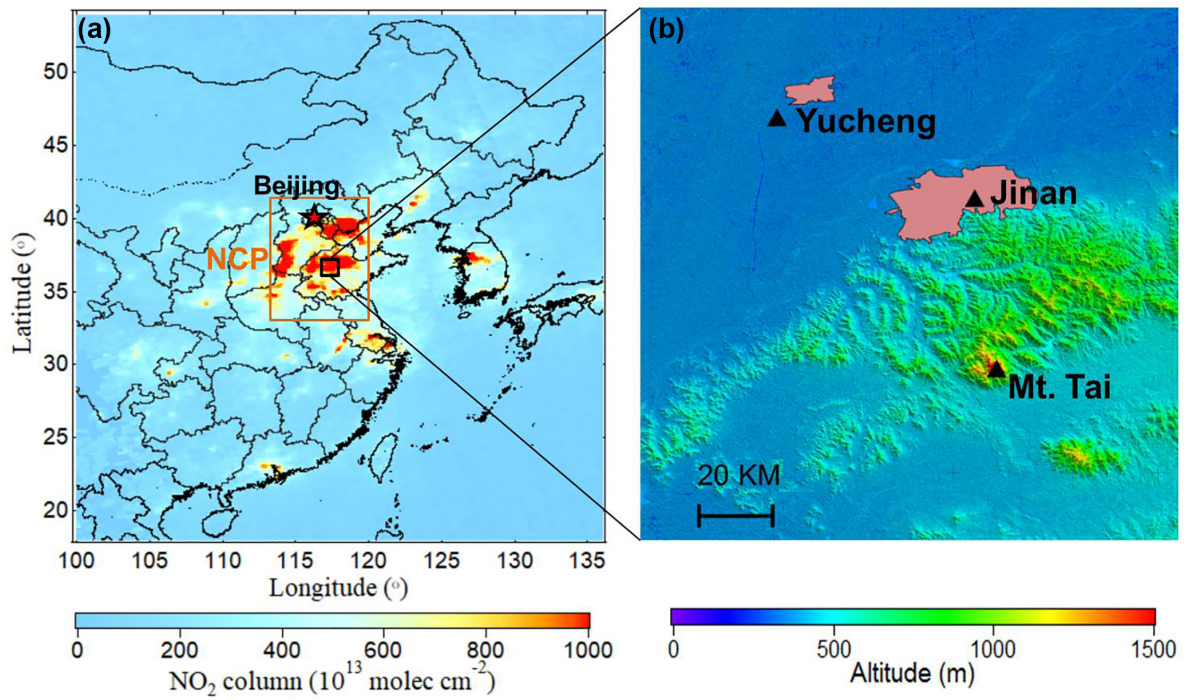

Figure 1. Map showing the study region and three measurement sites. Panel (a) is color coded with the OMI (Ozone Monitoring Instrument)retrieved tropospheric $\mathrm{NO}_{2}$ column density in July 2014, and panel (b) is color coded with the topographic height (the pink regions denote urban areas).

ous publications (Gao et al., 2011; Wang et al., 2015). Two intensive campaigns took place during 5-17 May 2014 and 23 August-21 September 2015. In addition, measurements of aerosol ionic components have been made previously at this site in selected years since 2005 (Yang et al., 2007, 2012; Gao et al., 2011; Zhu et al., 2015).

The rural site $\left(36.87^{\circ} \mathrm{N}, 116.57^{\circ} \mathrm{E} ; \sim 23 \mathrm{~m}\right.$ a.s.l. $)$ was set up at the Chinese Academy of Sciences Comprehensive Station in Yucheng. Although Yucheng belongs to Dezhou city, it serves as a satellite town of Jinan. The measurement site is located about $50 \mathrm{~km}$ northwest (normally downwind in summer) of downtown Jinan (Fig. 1) and can thus be regarded as a receptor site of urban pollution. The instruments were housed in a temperature-controlled container that was placed in open cropland with few anthropogenic emissions nearby (Wen et al., 2015; Zhu et al., 2016). A 6-week campaign was carried out here from 2 June to 16 July 2014.

The remote site $\left(36.26^{\circ} \mathrm{N}, 117.11^{\circ} \mathrm{E} ; 1465 \mathrm{~m}\right.$ a.s.l.) was installed at the summit of Mt. Tai. Mt. Tai is the highest mountain over the North China Plain (with a peak of 1534 ma.s.l.), and has been widely deployed as the sampling platform to investigate regional air pollution (Gao et al., 2005; Sun et al., 2016). The station was set up in a hotel to the north of the mountain peak with a little lower elevation. It is located approximately $15 \mathrm{~km}$ north of Tai' an city (with a population of 5.6 million) and $40 \mathrm{~km}$ south of urban Jinan (Fig. 1). Detailed descriptions of this site can be found elsewhere (Guo et al., 2012; Shen et al., 2012). In the present study, the measurements were conducted from 23 July to 27 August 2014. Previous data collected at Mt. Tai in summer 2007 are also analyzed to examine the long-term change in the regional nitrate pollution (Zhou et al., 2010).

\subsection{Measurement techniques}

A Monitor for AeRosols and GAses (MARGA; ADI20801, Applikon-ECN, Netherlands) was deployed in the present study to measure continuously, at a time resolution of $1 \mathrm{~h}$, inorganic water-soluble ions (i.e., $\mathrm{NO}_{3}^{-}, \mathrm{SO}_{4}^{2+}, \mathrm{NH}_{4}^{+}, \mathrm{Cl}^{-}$, etc.) in $\mathrm{PM}_{2.5}$ together with acid and alkaline gases (i.e., $\mathrm{HNO}_{3}, \mathrm{HCl}, \mathrm{NH}_{3}$, etc.). The target gases and ions are collected and dissolved by a wet rotating denuder (WRD) and a steam jet aerosol collector (SJAC), respectively (Brink et al., 2009). The dissolved components are then analyzed by a cationic and an anionic ion chromatography with eluent solutions of methane sulfonic acid $\left(308 \mathrm{mg} \mathrm{L}^{-1}\right)$ and $\mathrm{NaHCO}_{3}$ $\left(672 \mathrm{mg} \mathrm{L}^{-1}\right)-\mathrm{Na}_{2} \mathrm{CO}_{3}\left(742 \mathrm{mg} \mathrm{L}^{-1}\right)$. An internal standard solution of $\operatorname{LiBr}\left(4 \mathrm{mg} \mathrm{L}^{-1}\right)$ was added automatically to the collected sample solutions to calibrate the detection in each analytic process. Multipoint calibration was performed before and after the field campaigns to examine the sensitivity of the detectors. The detection limits were evaluated as $0.05,0.04$ and $0.05 \mu \mathrm{g} \mathrm{m}^{-3}$ for particulate $\mathrm{NO}_{3}^{-}, \mathrm{SO}_{4}^{2-}$ and $\mathrm{NH}_{4}^{+}$and $0.01,0.01$ and $0.07 \mathrm{ppbv}$ for gaseous $\mathrm{HNO}_{3}, \mathrm{SO}_{2}$ and $\mathrm{NH}_{3}$, respectively. The MARGA instrument has been deployed in many field studies in the high aerosol loading environment in China (e.g., Wen et al., 2015; Xie et al., 2015).

To achieve a detailed analysis of nitrate formation processes, a large suite of ancillary measurements were concurrently made during the field studies. $\mathrm{PM}_{2.5}$ mass concentrations were quantified in situ by a SHARP monitor (Model 5030, Thermo Scientific, USA); particle size and counts in the range of 5-10000 nm were monitored by a wide-range particle spectrometer (WPS; Model 1000XP, MSP Corporation, USA); $\mathrm{NO}$ and $\mathrm{NO}_{2}$ were monitored by a chemilumi- 
nescence instrument equipped with an internal molybdenum oxide $(\mathrm{MoO})$ catalytic converter (Model 42C, Thermo Electron Corporation, USA); $\mathrm{O}_{3}$ was monitored by an ultraviolet absorption analyzer (Model 49C, Thermo Electron Corporation, USA); $\mathrm{CO}$ was monitored by a nondispersive infrared analyzer (Model 300EU, API, USA); $\mathrm{SO}_{2}$ was monitored by an ultraviolet fluorescence analyzer (Model 43C, Thermo Electron Corporation, USA); meteorological parameters including temperature, relative humidity (RH) and wind sectors were monitored by commercial automatic weather stations. All of these techniques have been widely applied in many previous studies, for which there is detailed information (Gao et al., 2011; Wang et al., 2012; Xue et al., 2014).

\subsection{Multiphase chemical box model}

A zero-dimensional chemical box model was configured to simulate the in situ formation of fine nitrate aerosol. It couples the regional atmospheric chemistry mechanism version 2 (RACM2; including 363 chemical reactions) and the chemical aqueous-phase radical mechanism version 2.4 (CAPRAM 2.4; including 438 chemical reactions) to account for gas- and aqueous-phase atmospheric chemistry (Goliff et al., 2013; Herrmann et al., 2000, 2005). The gas-aqueousphase transfer processes were adopted from the resistance scheme of Schwartz (1986). This model explicitly describes the gas-to-aqueous phase partitioning of various chemical species, which connects the detailed chemical reactions in both gas and aqueous phases. The chemical reactions representing nitrate formation in the model are outlined in Table S1 in the Supplement. Briefly, these reactions can be divided into three major formation pathways, namely, the partitioning of gaseous $\mathrm{HNO}_{3}$ to the aerosol phase, hydrolysis reactions of $\mathrm{N}_{2} \mathrm{O}_{5}$ and aqueous-phase reactions of $\mathrm{NO}_{3}$ radicals. The $\mathrm{HNO}_{3}$ partitioning is largely affected by the availability of $\mathrm{NH}_{3}$, since the partitioning of $\mathrm{NH}_{3}$ would decrease the aerosol acidity and hence enhance the partitioning of $\mathrm{HNO}_{3}$ to the aerosol phase (see Table $\mathrm{S} 1$ in the Supplement). For the $\mathrm{N}_{2} \mathrm{O}_{5}$ hydrolysis process, the uptake coefficient of $\mathrm{N}_{2} \mathrm{O}_{5}$ on particles $\left(\gamma \mathrm{N}_{2} \mathrm{O}_{5}\right)$ is the parameter with large uncertainty in modeling studies. Recent studies have shown that $\gamma \mathrm{N}_{2} \mathrm{O}_{5}$ tends to be largely variable, and significant discrepancy exists between field-derived laboratory-derived parameterizations (Chang et al., 2011; McDuffie et al., 2018; Tham et al., 2018). The RACM-CAPRAM model does not take $\gamma \mathrm{N}_{2} \mathrm{O}_{5}$ into account but explicitly describes the $\mathrm{N}_{2} \mathrm{O}_{5}$ gas-to-aqueous phase partitioning as well as its subsequent aqueous-phase reactions. See Table S1 in the Supplement for the detailed treatment of the $\mathrm{N}_{2} \mathrm{O}_{5}$ hydrolysis processes in the model. We estimated the $\gamma\left(\mathrm{N}_{2} \mathrm{O}_{5}\right)$ from the reaction rate for the $\mathrm{N}_{2} \mathrm{O}_{5}$ gas-to-particle partitioning and the measured aerosol surface area concentrations and derived a $\gamma\left(\mathrm{N}_{2} \mathrm{O}_{5}\right)$ value of 0.018 for our selected cases. Such a level is well within the reported range of $\gamma\left(\mathrm{N}_{2} \mathrm{O}_{5}\right)$ derived from the field observations in other locations worldwide (e.g., 0.001-0.1), including several polluted areas in northern China (Tham et al., 2018; and references therein). This model has been utilized previously to simulate the nighttime nitrate formation in Beijing and Shanghai (Pathak et al., 2011).

The model calculation requires a large number of variables and parameters, including

1. gas phase concentrations of $\mathrm{NO}, \mathrm{NO}_{2}, \mathrm{O}_{3}, \mathrm{SO}_{2}, \mathrm{HCl}$, $\mathrm{HNO}_{2}, \mathrm{HNO}_{3}, \mathrm{NH}_{3}, \mathrm{CO}$ and VOCs (volatile organic compounds), etc.;

2. particulate (or aqueous) phase concentrations of $\mathrm{NO}_{3}^{-}$, $\mathrm{SO}_{4}^{2-}, \mathrm{Cl}^{-}, \mathrm{HSO}_{4}^{-}, \mathrm{NH}_{4}^{+}, \mathrm{H}^{+}, \mathrm{OH}^{-}$, etc.;

3. other auxiliary parameters such as temperature, $\mathrm{RH}$, pressure, boundary layer height, particle radius and aerosol water content.

Most of the above parameters were observed in situ during our intensive measurement campaigns, and the available data were directly used to constrain the model. The measured aerosol ions data such as nitrate, sulfate and ammonium were only used as initial conditions of the model simulation. The model was initialized with the measured nitrate concentration at the beginning of the episodes, and then simulated its formation with constraints of other relevant species. The particle radius was calculated from the measured aerosol number and size distribution with an assumption that all particles were spherical. A hygroscopic growth factor obtained from the NCP region by Achtert et al. (2009) was adopted to take into account the effect of hygroscopic growth on the particle size and surface. Aerosol $\mathrm{H}^{+}, \mathrm{OH}^{-}, \mathrm{HSO}_{4}^{-}$, and water content were simulated by a thermodynamic model (EAIM; http://www.aim.env.uea.ac.uk/aim/aim.php) based on the measured aerosol chemistry data (Clegg et al., 1998; Zhang et al., 2000). The VOC measurements were not made during the present study, and we used the campaign average data previously collected in the same areas during summertime for approximation (Wang et al., 2015; Zhu et al., 2016, 2017). The detailed VOC species and their concentrations as model input are documented in Table S3 in the Supplement. We conducted sensitivity tests with 0.5 or 1.5 times of the initial VOC concentrations and found that the model simulation was somewhat insensitive to the initial VOC data (the differences in the model-simulated nitrate formation between sensitivity tests and base run were within $12 \%$; see Fig. S1 in the Supplement). This likely to be mainly due to the low levels of biogenic VOCs in the study area. Given the lack of in situ VOC measurements, however, the treatment of VOC data presents a major uncertainty in the present modeling analyses. The boundary layer height, which affects the dry deposition of various constituents, was estimated by the Nozaki method (Nozaki, 1973). The dry deposition velocity of $\mathrm{HNO}_{3}$ was set to $2 \mathrm{~cm} \mathrm{~s}^{-1}$ in the model. With such a configuration, dry deposition only presents a minor fraction of the daytime $\mathrm{HNO}_{3} \operatorname{sink}(<1 \%)$, compared to the $\mathrm{HNO}_{3}$ gas-to-particle partitioning. 
Simulations were conducted for selected nighttime or daytime nitrate formation cases. The starting time and simulation periods depended on the individual cases. The output data included particulate nitrate concentrations and reaction rates of the major aerosol formation pathways. In addition, a number of sensitivity simulations were performed to examine the relationships between nitrate formation and its precursors (see Sects. 3.3 and 3.4).

\section{Results and discussions}

\subsection{Temporal and spatial variations}

Table 1 summarizes the statistics of the aerosol chemical properties, trace gases and meteorological parameters measured at three study sites. It clearly shows the spatial distribution of regional aerosol pollution though elevated levels of $\mathrm{PM}_{2.5}$, and major ions were observed at all three sites. The highest $\mathrm{PM}_{2.5}$ levels were recorded at the receptor rural site (Yucheng; with a campaign average \pm SD of $97.9 \pm 53.0 \mu \mathrm{g} \mathrm{m}^{-3}$ ), followed by the urban (Jinan; $68.4 \pm 41.7$ and $59.3 \pm 31.8 \mu \mathrm{g} \mathrm{m}^{-3}$ in 2014 and 2015 , respectively) and mountain sites (Mt. Tai; $50.2 \pm 31.7 \mu \mathrm{g} \mathrm{m}^{-3}$ ). Nitrate shows a similar gradient, with average concentrations ranging from $6.0 \pm 4.6 \mu \mathrm{g} \mathrm{m}^{-3}$ at Mt. Tai to $13.6 \pm 10.3 \mu \mathrm{g} \mathrm{m}^{-3}$ at Yucheng. In comparison, $\mathrm{SO}_{4}^{2-}$ shows a slightly different pattern with the lowest levels found in Jinan $\left(12.2 \pm 7.5\right.$ and $\left.12.7 \pm 7.9 \mu \mathrm{g} \mathrm{m}^{-3}\right)$ and then Mt. Tai $\left(14.7 \pm 8.9 \mu \mathrm{g} \mathrm{m}^{-3}\right)$ and Yucheng $\left(23.6 \pm 13.4 \mu \mathrm{g} \mathrm{m}^{-3}\right)$. Chloride showed comparable levels in urban Jinan $(1.3 \pm 2.1$ and $\left.1.3 \pm 1.7 \mu \mathrm{g} \mathrm{m}^{-3}\right)$ and rural Yucheng $\left(1.2 \pm 1.2 \mu \mathrm{g} \mathrm{m}^{-3}\right)$, with a relatively lower level at Mt. Tai $\left(0.7 \pm 0.5 \mu \mathrm{g} \mathrm{m}^{-3}\right)$. For $\mathrm{NO}_{2}$, an anthropogenic emission indicator and a major precursor of $\mathrm{NO}_{3}^{-}$, the highest mixing ratios were determined in urban Jinan, followed by Yucheng and Mt. Tai. The nitrate oxidation ratio (NOR), defined as the molar ratio of $\mathrm{NO}_{3}^{-}$ to $\mathrm{NO}_{3}^{-}+\mathrm{NO}_{x}$, shows an opposite pattern with the lowest values in Jinan $(0.11 \pm 0.07$ and $0.16 \pm 0.08$ in 2014 and $2015)$ and the highest levels at Mt. Tai $(0.39 \pm 0.20)$. This indicates the different extent of chemical processing of air masses in different types of areas. The air masses sampled at Mt. Tai were more aged and longer air transport allowed more time for chemical processing. The above regional gradients of air pollution are mainly due to the spatial distribution of anthropogenic emissions and different chemical aging of air masses. It should be noted that these measurements were not conducted simultaneously, and thus differences in the reported data at the three study sites can be expected in view of the potential differences in the meteorological conditions which affect atmospheric mixing and transport processes. However, the spatial distributions of emissions, atmospheric chemical and physical processes are still believed to be the major factor shaping the observed regional pattern of aerosol pollution.
Table 1 also illustrates some homogeneity of the regional aerosol pollution and chemistry in the NCP region. First, secondary inorganic ions (i.e., $\mathrm{SO}_{4}^{2-}, \mathrm{NO}_{3}^{-}$and $\mathrm{NH}_{4}^{+}$) accounted for, on average, $41-56 \%$ of $\mathrm{PM}_{2.5}$ at three sites, indicating their dominant roles in the aerosol composition and regional haze. Second, $\mathrm{NO}_{3}^{-}$alone presented an important fraction of fine particles, and the $\mathrm{NO}_{3}^{-} / \mathrm{PM}_{2.5}$ ratios were nearly uniform over the region, with average values of $11-14 \%$ at all three sites. Based on field measurements in January 2013, Huang (2014) also reported that $\mathrm{NO}_{3}^{-}$accounted for 12, 14 and $13 \%$ of $\mathrm{PM}_{2.5}$ in Beijing, Shanghai and Guangzhou, with a smaller ratio $(7 \%)$ recorded in a western city (Xi'an). At the surface sites (i.e., Jinan and Yucheng) in the present study, the molar concentrations of $\mathrm{NO}_{3}^{-}$were even comparable to $\mathrm{SO}_{4}^{2-}$, with mean $\mathrm{NO}_{3}^{-} / \mathrm{SO}_{4}^{2-}$ ratios of 0.93-1.04. In comparison, the $\mathrm{NO}_{3}^{-} / \mathrm{SO}_{4}^{2-}$ ratio was lower $(0.62 \pm 0.33)$ at Mt. Tai, which is likely to be due to the longer lifetime of sulfate aerosol and frequent transport of power plant plumes to the mountain site (Z. Wang et al., 2017). Finally, $\mathrm{NH}_{4}^{+}$was generally in excess in $\mathrm{PM}_{2.5}$. The average excess $\mathrm{NH}_{4}^{+}$(excess $\left.\mathrm{NH}_{4}^{+}=18 \cdot\left(\left[\mathrm{NH}_{4}^{+}\right]-1.5 \cdot\left[\mathrm{SO}_{4}^{2-}\right]-\left[\mathrm{NO}_{3}^{-}\right]-\left[\mathrm{Cl}^{-}\right]\right)\right)$was calculated to be in the range of $0.9-4.3 \mu \mathrm{g} \mathrm{m}^{-3}$ at our three study sites. This highlights the $\mathrm{NH}_{3}$-rich chemical environment of the NCP region, and the abundant $\mathrm{NH}_{3}$ may significantly affect the formation of nitrate aerosol (see Sect. 3.4).

Figure 2 clearly shows the distinct diurnal variation patterns of $\mathrm{NO}_{3}^{-}$and $\mathrm{NO}_{2}$ at the three different types of sites. In urban Jinan, $\mathrm{NO}_{3}^{-}$showed a maximum level in the early morning (08:00 local time, LT) with a secondary peak in the afternoon (15:00 LT). At Yucheng, the average diurnal profile displays a continuous nitrate formation process throughout the nighttime with a $\mathrm{NO}_{3}^{-}$increase of $16.9 \mu \mathrm{g} \mathrm{m}^{-3}$ from 16:00 to 08:00 LT, followed by a sharp decrease during the day with a trough in the late afternoon (16:00 LT). The absolute nighttime $\mathrm{NO}_{3}^{-}$levels were higher than the daytime concentrations at Jinan and Yucheng, owing to the dilution within the developed planetary boundary layer (PBL) and thermal decomposition of aerosol in high temperature conditions during the day. An opposite diurnal profile was observed at Mt. Tai, which showed an $\mathrm{NO}_{3}^{-}$increase throughout the daytime and high concentrations remaining in the early evening. The daytime increase was due to the development of the PBL and the mountain-valley breeze, both of which could carry the boundary layer pollution aloft, and the elevated evening levels should be ascribed to the regional transport of polluted plumes to the mountain top (Sun et al., 2016). Overall, $\mathrm{NO}_{2}$ showed similar diurnal variations with $\mathrm{NO}_{3}^{-}$, and the $\mathrm{NO}_{3}^{-}$concentration peaks generally lagged behind $\mathrm{NO}_{2}$, suggesting the role of $\mathrm{NO}_{2}$ in nitrate formation as a precursor. The inspection of diurnal variations day by day also revealed frequent nitrate formation at all three sites during nighttime and also during the day (especially at Mt. Tai). We then selected a dozen of nitrate formation cases for detailed modeling analyses in Sect. 3.3. 
Table 1. Statistics (average \pm standard deviation) of the measured aerosol chemical properties, trace gases and meteorological conditions in urban Jinan, rural Yucheng and Mt. Tai.

\begin{tabular}{|c|c|c|c|c|}
\hline Site & Jinan (urban) & Jinan (urban) & Yucheng (rural) & Mt. Tai (remote) \\
\hline Period & May 2014 & Aug-Sep 2015 & Jun-Jul 2014 & Jul-Aug 2014 \\
\hline $\mathrm{NO}_{3}^{-}\left(\mu \mathrm{g} \mathrm{m}^{-3}\right)$ & $8.8 \pm 8.2$ & $7.4 \pm 5.1$ & $13.6 \pm 10.3$ & $6.0 \pm 4.6$ \\
\hline $\mathrm{SO}_{4}^{2-}\left(\mu \mathrm{g} \mathrm{m}^{-3}\right)$ & $12.2 \pm 7.5$ & $12.7 \pm 7.9$ & $23.6 \pm 13.4$ & $14.7 \pm 8.9$ \\
\hline $\mathrm{NH}_{4}^{+}\left(\mu \mathrm{g} \mathrm{m}^{-3}\right)$ & $6.8 \pm 5.3$ & $11.1 \pm 8.2$ & $11.9 \pm 7.7$ & $7.3 \pm 5.0$ \\
\hline $\mathrm{Cl}^{-}\left(\mu \mathrm{g} \mathrm{m}^{-3}\right)$ & $1.3 \pm 2.1$ & $1.3 \pm 1.7$ & $1.2 \pm 1.2$ & $0.7 \pm 0.5$ \\
\hline $\mathrm{PM}_{2.5}\left(\mu \mathrm{g} \mathrm{m}^{-3}\right)$ & $68.4 \pm 41.7$ & $59.3 \pm 31.8$ & $97.9 \pm 53.0$ & $50.2 \pm 31.7$ \\
\hline $\mathrm{NO}_{3}^{-} / \mathrm{PM}_{2.5}$ & $0.12 \pm 0.06$ & $0.14 \pm 0.07$ & $0.14 \pm 0.07$ & $0.11 \pm 0.05$ \\
\hline $\mathrm{SO}_{4}^{2-} / \mathrm{PM}_{2.5}$ & $0.18 \pm 0.06$ & $0.24 \pm 0.10$ & $0.27 \pm 0.12$ & $0.30 \pm 0.11$ \\
\hline $\mathrm{NH}_{4}^{+} / \mathrm{PM}_{2.5}$ & $0.10 \pm 0.05$ & $0.18 \pm 0.11$ & $0.13 \pm 0.06$ & $0.15 \pm 0.07$ \\
\hline $\mathrm{Cl}^{-} / \mathrm{PM}_{2.5}$ & $0.015 \pm 0.016$ & $0.024 \pm 0.027$ & $0.012 \pm 0.010$ & $0.019 \pm 0.025$ \\
\hline$\left[\mathrm{NO}_{3}^{-}\right] /\left[\mathrm{SO}_{4}^{2-}\right]$ & $1.04 \pm 0.46$ & $0.98 \pm 0.49$ & $0.93 \pm 0.53$ & $0.62 \pm 0.33$ \\
\hline $\mathrm{NO}_{2}(\mathrm{ppb})$ & $20.5 \pm 9.0$ & $14.1 \pm 4.5$ & $16.6 \pm 10.7$ & $3.0 \pm 2.3$ \\
\hline $\mathrm{O}_{3}(\mathrm{ppb})$ & $31 \pm 19$ & $43 \pm 36$ & $38 \pm 26$ & $75 \pm 21$ \\
\hline $\mathrm{SO}_{2}(\mathrm{ppb})$ & $10.4 \pm 11.1$ & $7.1 \pm 4.6$ & $4.2 \pm 7.4$ & $2.4 \pm 2.8$ \\
\hline $\mathrm{CO}(\mathrm{ppb})$ & $1835 \pm 2046$ & - & $622 \pm 280$ & $609 \pm 214$ \\
\hline Particle diameter (nm) & $41 \pm 12$ & $55 \pm 50$ & $78 \pm 34$ & $66 \pm 21$ \\
\hline Particle number $\left(10^{3} \#_{\mathrm{cm}^{-3}}\right)$ & $7.1 \pm 4.1$ & $12 \pm 8.3$ & $3.0 \pm 3.8$ & $3.4 \pm 2.8$ \\
\hline $\mathrm{NOR}^{\mathrm{a}}$ & $0.11 \pm 0.07$ & $0.16 \pm 0.08$ & $0.24 \pm 0.13$ & $0.39 \pm 0.20$ \\
\hline Excess $\mathrm{NH}_{4}^{+}\left(\mu \mathrm{g} \mathrm{m}^{-3}\right)^{\mathrm{b}}$ & $2.0 \pm 2.4$ & $4.3 \pm 6.4$ & $0.9 \pm 2.5$ & $1.0 \pm 1.8$ \\
\hline$T\left({ }^{\circ} \mathrm{C}\right)$ & $22.2 \pm 4.2$ & $23.6 \pm 3.4$ & $25.4 \pm 4.7$ & $18.0 \pm 2.7$ \\
\hline $\mathrm{RH}(\%)$ & $38.8 \pm 19.7$ & $66.0 \pm 21.0$ & $70.3 \pm 19.8$ & $86.9 \pm 12.8$ \\
\hline
\end{tabular}

a $\mathrm{NOR}$ (nitrate oxidation ratio $)=\left[\mathrm{NO}_{3}^{-}\right] /\left(\left[\mathrm{NO}_{3}^{-}\right]+\left[\mathrm{NO}_{x}\right]\right) ;{ }^{\mathrm{b}}$ Excess $\mathrm{NH}_{4}^{+}=\left(\left[\mathrm{NH}_{4}^{+}\right]-1.5 \cdot\left[\mathrm{SO}_{4}^{2-}\right]-\left[\mathrm{NO}_{3}^{-}\right]-\left[\mathrm{Cl}^{-}\right]\right) \cdot 18$.

Note that $\left[\mathrm{NO}_{3}^{-}\right],\left[\mathrm{NO}_{x}\right],\left[\mathrm{NH}_{4}^{+}\right],\left[\mathrm{SO}_{4}^{2-}\right]$ and $\left[\mathrm{Cl}^{-}\right]$are molar concentrations of $\mathrm{NO}_{3}^{-}, \mathrm{NO}_{x}, \mathrm{NH}_{4}^{+}, \mathrm{SO}_{4}^{2-}$ and $\mathrm{Cl}^{-}$, respectively.
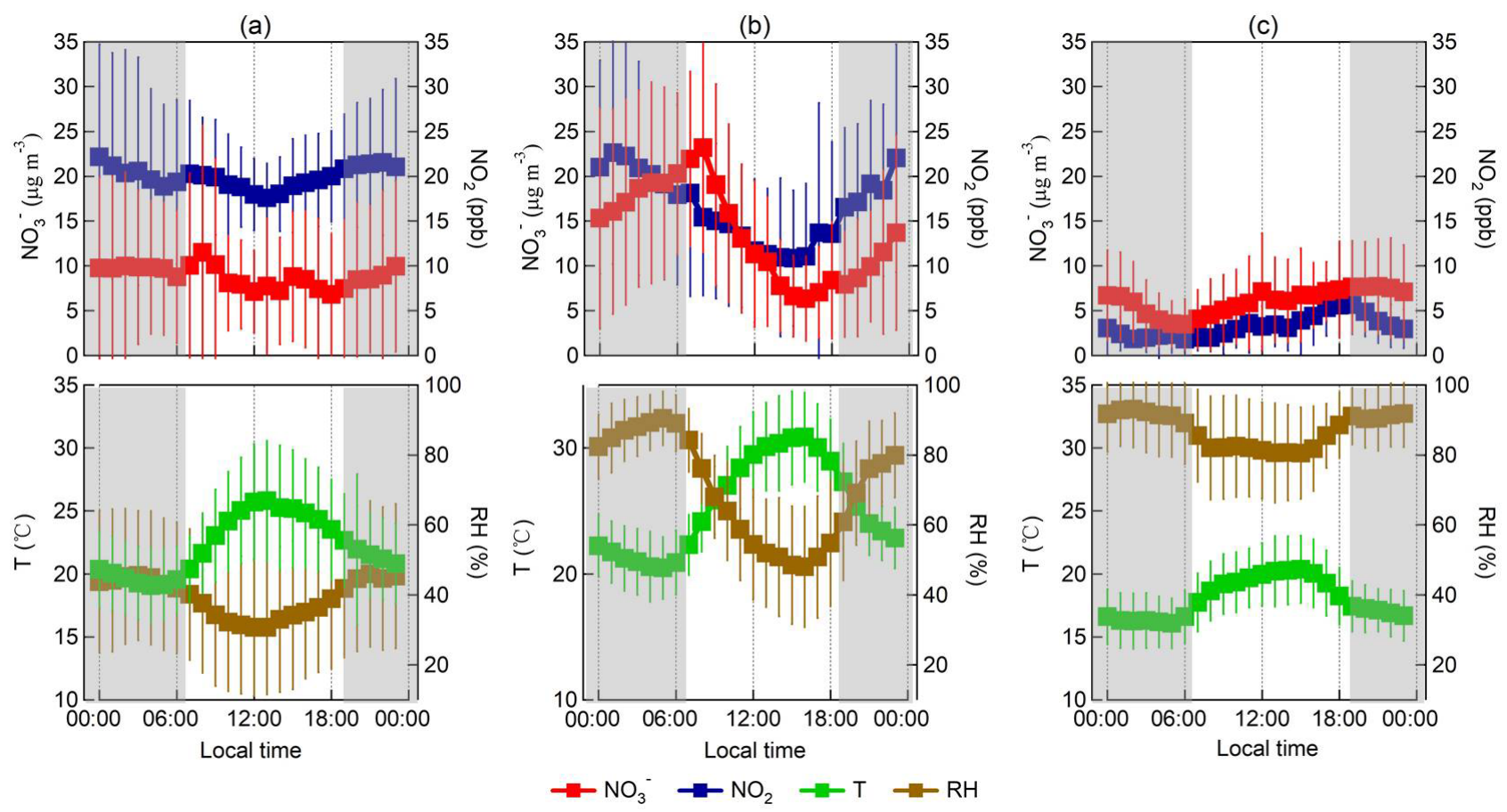

Figure 2. Average diurnal variations in fine particulate $\mathrm{NO}_{3}^{-}, \mathrm{NO}_{2}$ and meteorological conditions in (a) urban Jinan in May 2014, (b) rural Yucheng and (c) Mt. Tai. Error bars stand for the standard deviation of the measurements. The shaded area denotes the nighttime period. 

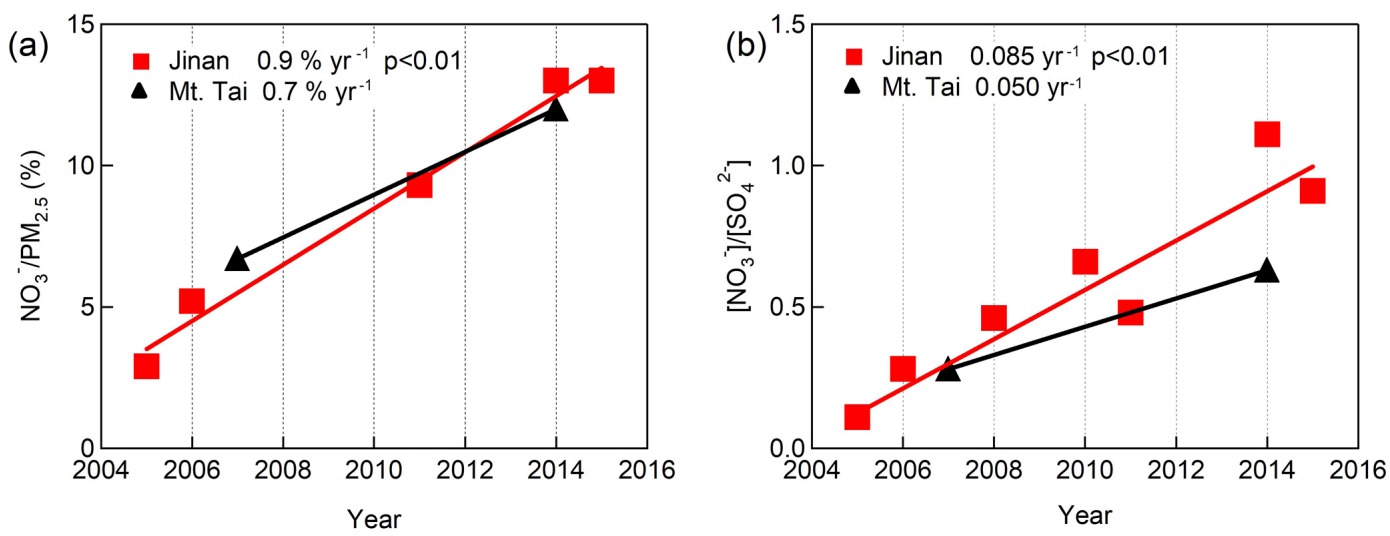

Figure 3. Long-term trends of (a) mass ratio of $\mathrm{NO}_{3}^{-} / \mathrm{PM}_{2.5}$ and (b) molar ratio of $\mathrm{NO}_{3}^{-} / \mathrm{SO}_{4}^{2-}$ in urban Jinan and at Mt. Tai in summertime from 2005 to 2015 . The fitted lines are derived from the least square linear regression analysis, with the slopes and $p$ values (99\% confidence intervals) denoted.

\subsection{Trend over 2005-2015}

Figure 3 shows the increasing trends of $\mathrm{NO}_{3}^{-}$in $\mathrm{PM}_{2.5}$ in the past decade over the NCP region. Intensive measurements of aerosol ionic species have been made by our group in urban Jinan in selected years since 2005 (Yang et al., 2007, 2012; Gao et al., 2011; Zhu et al., 2015) and at Mt. Tai in 2007 (Zhou et al., 2010), and these previous data were combined with the more recent observations in the present study to derive the decadal trends. To eliminate the interference of interannual variation in weather conditions on the absolute concentrations, we focused on the ratios of $\mathrm{NO}_{3}^{-} / \mathrm{PM}_{2.5}$ and $\mathrm{NO}_{3}^{-} / \mathrm{SO}_{4}^{2-}$ for the trend analysis. In urban Jinan, the fraction of $\mathrm{NO}_{3}^{-}$in $\mathrm{PM}_{2.5}$ has increased at a rate of $0.9 \%$ per year over 2005-2015 $(p<0.01)$. A similar increasing rate $(0.7 \%$ per year) was also derived at Mt. Tai from data collected in 2007 to 2014, affirming the statistically significant increase in fine particulate nitrate over the region. At the same time, the $\mathrm{SO}_{4}^{2-}$ in $\mathrm{PM}_{2.5}$ has statistically significantly declined in urban Jinan $(-0.7 \%$ per year) and at Mt. Tai $(-1.3 \%$ per year; figures not shown), as a result of the strict control of $\mathrm{SO}_{2}$ emissions in China. As a result, the molar ratio of $\mathrm{NO}_{3}^{-} / \mathrm{SO}_{4}^{2-}$ has increased at a rate of 0.09 per year in Jinan during 2005-2015 $(p<0.01)$ and 0.05 per year at Mt. Tai from 2007 to 2014 (Fig. 3b).

We also examined the trends in the absolute concentrations of $\mathrm{PM}_{2.5}$, nitrate and sulfate in urban Jinan and at Mt. Tai (see Fig. S2 in the Supplement). As expected, the ambient concentrations of $\mathrm{PM}_{2.5}\left(-6.3\right.$ and $\left.-1.4 \mu \mathrm{g} \mathrm{m}^{-3} \mathrm{yr}^{-1}\right)$ and $\mathrm{SO}_{4}^{2-}\left(-2.1\right.$ and $\left.-1.2 \mu \mathrm{g} \mathrm{m}^{-3} \mathrm{yr}^{-1}\right)$ have rapidly decreased at both locations during the past decade, which should be largely attributed to the stringent control of $\mathrm{SO}_{2}$ emissions and primary particles. In comparison, the absolute concentrations of $\mathrm{NO}_{3}^{-}$showed an increasing trend with average rates of change of 0.39 and $0.29 \mu \mathrm{g} \mathrm{m}^{-3} \mathrm{yr}^{-1}$ at Jinan and Mt. Tai, respectively. This confirms the increase in absolute nitrate aerosol pollution in the NCP region. Nevertheless, the available observations since 2011 also showed a decrease in the absolute levels of nitrate aerosol in Jinan. This trend may be true considering the strict $\mathrm{NO}_{x}$ emission control of China since 2011, but it may be also partly interfered by the higher aerosol pollution observed during the campaign of 2011 with unfavorable meteorological conditions. More measurement efforts are urgently needed to further examine the recent trend of nitrate aerosol after 2011 and evaluate the impact of the $\mathrm{NO}_{x}$ emission control of China.

Our observations provide direct evidence of a statistically significant increase in summertime nitrate aerosol in the NCP region along with a decrease in sulfate in the last decade. The comparable contributions of $\mathrm{NO}_{3}^{-}$and $\mathrm{SO}_{4}^{2-}$ to $\mathrm{PM}_{2.5}$ suggest the gradual shift of the secondary inorganic aerosol type from $\mathrm{SO}_{4}^{2-}$-dominant to $\mathrm{NO}_{3}^{-}$-and- $\mathrm{SO}_{4}^{2-}$-dominant. A recent modeling study also predicted an increase in nitrate with a decrease in sulfate from 2006 to 2015 over all of eastern China (Wang et al., 2013). A more recent observational study at two sites (Beijing and Xinxiang) in the NCP region indicated the important contributions of nitrate in $\mathrm{PM}_{1}$ and its driving role in the summertime haze pollution ( $\mathrm{Li}$ et al., 2018). Overall, nitrate has been playing an increasingly important role in the haze pollution in northern China. In recent years, the strict antipollution measures implemented by the central government have led to a significant reduction in the primary $\mathrm{PM}_{2.5}$ in the NCP, while secondary aerosols such as nitrate are still at high levels and present the major challenge for further mitigation of haze pollution (http: //www.cnemc.cn/kqzlzkbgyb2092938.jhml). Nitrate and its precursors should be the next major target for the future control of regional haze pollution in China.

\subsection{Nitrate formation mechanisms}

Multiphase chemical modeling was then conducted for typical nitrate formation events to understand the formation 


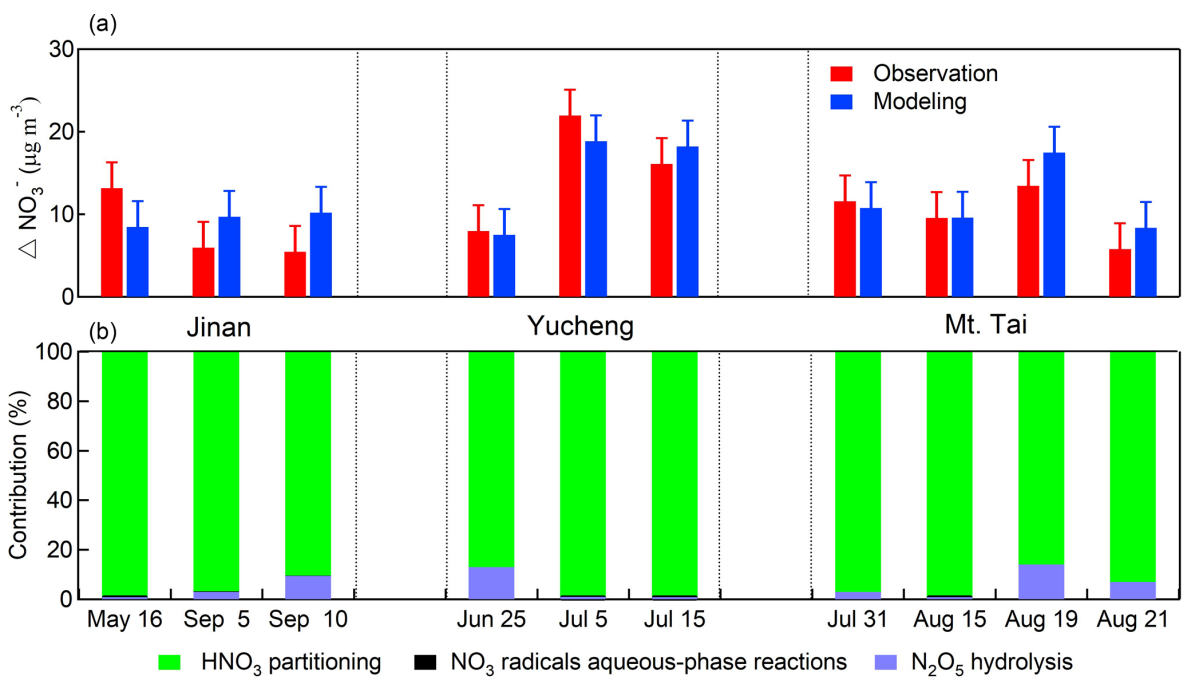

Figure 4. Comparison of the model-simulated versus observed nitrate enhancement (a) as well as the contributions from the major three formation pathways (b) for the daytime cases in urban Jinan, rural Yucheng and Mt. Tai. The error bars are the standard error of the differences between simulated and observed increase in nitrate aerosol.

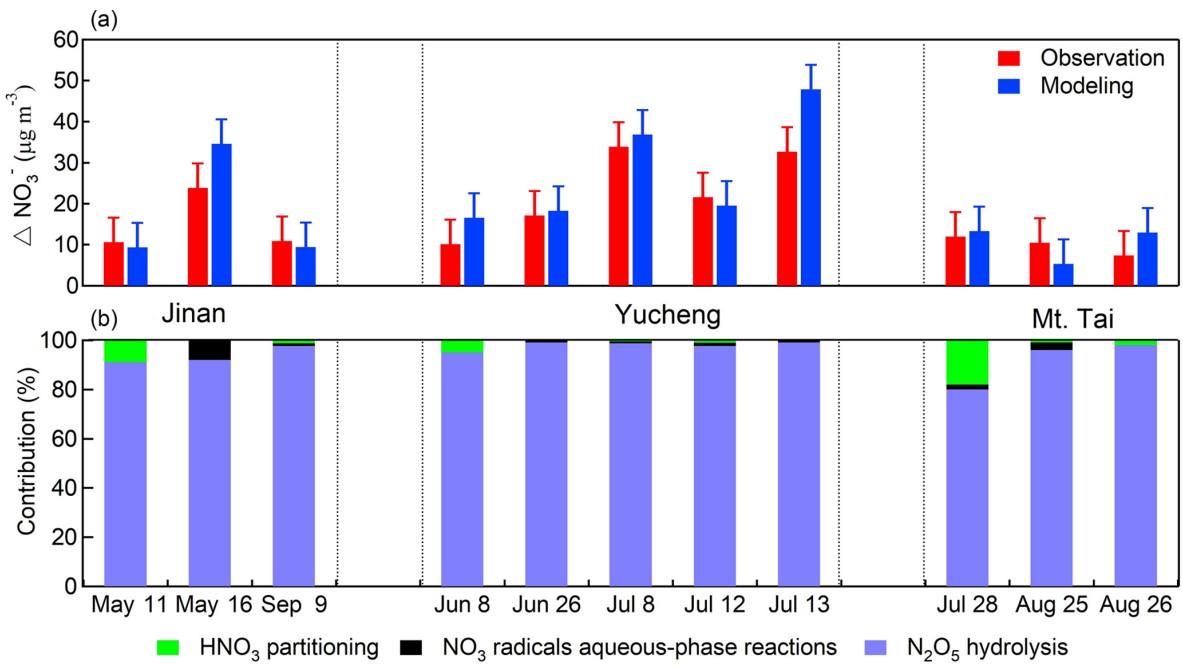

Figure 5. The same as Fig. 4 but for the selected nocturnal nitrate formation cases.

mechanisms of fine particulate nitrate at three study sites. The selected cases met the following criteria:

1. The nitrate formation (accumulation) process should last for a considerable time period (i.e., at least $3 \mathrm{~h}$ ).

2. The observed NOR $\left(\mathrm{NOR}=\left[\mathrm{NO}_{3}^{-}\right] /\left(\left[\mathrm{NO}_{3}^{-}\right]+\left[\mathrm{NO}_{x}\right]\right)\right.$ increased throughout the event.

3. The meteorological conditions were stable with a constant wind direction or calm conditions and without wet deposition.

4. The data in the early morning period (i.e., 06:0009:00 LT) were excluded from analyses to roughly eliminate the potential influence from downward mixing of air aloft to the surface sites. A total of 21 nitrate formation events were finally selected, including 10 daytime cases (3, 3 and 4 in Jinan, Yucheng and Mt. Tai) and 11 nighttime ones $(3,5$ and 3 in Jinan, Yucheng and Mt. Tai). Details of these selected cases are provided in the Supplement (see Table S4).

Figure 4 compares the model-simulated versus observed nitrate enhancements for the daytime cases and also presents the contributions of the major nitrate formation pathways. Generally, the model reproduced the observed nitrate formation well, with a strong positive correlation between simulations and observations (with a reduced major axis (RMA) slope of 0.90 and $r^{2}$ of 0.60 ; see Fig. S3 in the Supplement). The partitioning of $\mathrm{HNO}_{3}$ gas to the particulate phase was 
clearly the predominant daytime formation pathway of nitrate aerosol, with average contributions of 96, 95 and $94 \%$ at the urban, rural and remote sites, respectively. Hydrolysis of $\mathrm{N}_{2} \mathrm{O}_{5}$ contributed to the remaining nitrate (4-6\%), and the direct uptake and aqueous-phase reactions of $\mathrm{NO}_{3}$ radicals were negligible.

The modeling results for the nighttime cases are shown in Fig. 5. The model also worked reasonably well for the simulation of nitrate formation at night, as indicated by the strong positive correlation between the simulated and observed $\mathrm{NO}_{3}^{-}$enhancements with a RMA slope (simulation/observation) of 1.60 and $r^{2}$ of 0.93 (see Fig. S3 in the Supplement). Figure S4 shows that the model reproduced the absolute concentrations of nitrate for two specific typical cases. The hydrolysis reaction of $\mathrm{N}_{2} \mathrm{O}_{5}$ turned out to be the overwhelming formation pathway at nighttime, with mean contributions of 94,98 and $91 \%$ at the urban, rural and remote sites, respectively. Other processes such as the $\mathrm{HNO}_{3}$ partitioning and aqueous reactions of $\mathrm{NO}_{3}$ radicals were minor routes. These results are in line with the previous studies that have assessed the nitrate formation pathways. For example, Pathak et al. (2011) found that the $\mathrm{N}_{2} \mathrm{O}_{5}$ hydrolysis contributed to $50-100 \%$ of the nocturnal nitrate formation in Beijing and Shanghai. Based on the field measurements of $\mathrm{N}_{2} \mathrm{O}_{5}$ and related species, H. Wang et al. (2017) suggested that the $\mathrm{N}_{2} \mathrm{O}_{5}$ hydrolysis contributed comparably to or even higher than the partitioning of $\mathrm{HNO}_{3}$ to nitrate formation in Beijing on a daily basis. Overall, the significant roles of $\mathrm{HNO}_{3}$ partitioning and $\mathrm{N}_{2} \mathrm{O}_{5}$ hydrolysis in nitrate formation have been outlined well (Brown and Stutz, 2012).

The budgets of nitrate formation were almost the same among the three study sites. This indicates the regional homogeneity of formation mechanism of fine nitrate aerosol over the NCP region. The formation of $\mathrm{HNO}_{3}$ and its subsequent partitioning to the aerosol phase is the principal formation route during the day, while the hydrolysis reactions of $\mathrm{N}_{2} \mathrm{O}_{5}$ on the particles play a dominant role during the night. This is in line with the current understanding that the oxidation of $\mathrm{NO}_{2}$ by $\mathrm{OH}$ forming $\mathrm{HNO}_{3}$ and heterogeneous reactions of $\mathrm{N}_{2} \mathrm{O}_{5}$ present the major $\mathrm{NO}_{x}$ sinks during the daytime and nighttime, respectively (Liu et al., 2013).

According to the above identified major formation pathways, nitrate formation can be influenced by the availability of $\mathrm{NO}_{x}, \mathrm{O}_{3}$ and $\mathrm{NH}_{3}$. $\mathrm{NO}_{x}$ are direct precursors of nitrate formation. $\mathrm{O}_{3}$ is a major oxidant and supplier of $\mathrm{OH}$ radicals during the day and is also a precursor of $\mathrm{N}_{2} \mathrm{O}_{5}$ at night. $\mathrm{NH}_{3}$ may prompt the partitioning of $\mathrm{HNO}_{3}$ to the aerosols and alter the aerosol acidity that affects not only the partitioning of $\mathrm{HNO}_{3}$ but also the hydrolysis of $\mathrm{N}_{2} \mathrm{O}_{5}$. Therefore, we further examined the dependence of nitrate formation on $\mathrm{NO}_{2}$, $\mathrm{O}_{3}$ and $\mathrm{NH}_{3}$ at the three sites by sensitivity analyses. Sensitivity modeling calculations were conducted by adjusting the concentrations of the target species $\left(\mathrm{NO}_{2}\right.$ or $\mathrm{O}_{3}$ or $\left.\mathrm{NH}_{3}\right)$ by $X$ times (i.e., 0, 0.1, 0.2, 0.3, 0.4, 0.5, 0.8, 1.2 and 1.5), and the other settings remained unchanged with the base simulations.
The difference in the simulated $\mathrm{NO}_{3}^{-}$concentrations between base and sensitivity runs is like to reflect the impact of the change in the target species on nitrate formation. The sensitivity modeling results for the daytime cases are documented in Fig. 6. Similar results were derived from the three different study areas. During the day, nitrate formation was the most sensitive to $\mathrm{NO}_{2}$, a necessary precursor of $\mathrm{NO}_{3}^{-}$aerosol. It was also sensitive to a lesser extent to $\mathrm{O}_{3}$, which is a major $\mathrm{OH}$ source and thus affects the gaseous $\mathrm{HNO}_{3}$ formation. An interesting finding was the dependence of nitrate formation to the abundance of $\mathrm{NH}_{3}$. Adjusting (neither increasing nor decreasing) the currently measured $\mathrm{NH}_{3}$ concentrations by up to $50 \%$ would not lead to significant changes in the model simulated $\mathrm{NO}_{3}^{-}$, whilst further reduction in $\mathrm{NH}_{3}$ (more than ca. 50-80\%) would result in a significant decrease in $\mathrm{NO}_{3}^{-}$. This indicates that $\mathrm{NH}_{3}$ plays an important role in nitrate formation, but it is now highly in excess in the NCP region so that nitrate formation is somewhat insensitive to $\mathrm{NH}_{3}$.

Figure 7 presents the dependence of nitrate formation to $\mathrm{NO}_{2}, \mathrm{O}_{3}$ and $\mathrm{NH}_{3}$ for the nighttime cases. Again, the results obtained from the three study sites were similar. Nitrate formation was very sensitive to both $\mathrm{NO}_{2}$ and $\mathrm{O}_{3}$. Adjusting the abundances of $\mathrm{NO}_{2}$ or $\mathrm{O}_{3}$ would lead to almost a linear response in the model-simulated nitrate formation. As discussed above, the nocturnal nitrate formation was mainly controlled by the hydrolysis reactions of $\mathrm{N}_{2} \mathrm{O}_{5}$, which is the product of the reactions of $\mathrm{NO}_{2}$ with $\mathrm{O}_{3}$. In comparison, nitrate formation was not sensitive to $\mathrm{NH}_{3}$ at all three sites. Interestingly, large reductions in $\mathrm{NH}_{3}$ (ca. $>60 \%$ at Yucheng and $>90 \%$ in Jinan) would result in a slight increase in the $\mathrm{NO}_{3}^{-}$aerosol formation. This is likely to be due to the increase in aerosol acidity by reducing the $\mathrm{NH}_{3}$ levels, which could change the partitioning of the formation of both nitrate and $\mathrm{ClNO}_{2}$ from the $\mathrm{N}_{2} \mathrm{O}_{5}$ hydrolysis. Increasing the aerosol acidity would restrict the reaction of $\mathrm{NO}_{2}^{+}$with $\mathrm{Cl}^{-}$yielding $\mathrm{ClNO}_{2}$ and hence enhance the formation of nitrate aerosol (Roberts et al., 2008). We conducted sensitivity tests without the inputs of $\mathrm{Cl}^{-}$, and the results did not show any increase in nitrate formation with reduction in $\mathrm{NH}_{3}$ (figures not shown).

It should be noted that the Mt. Tai site is located at around 1465 ma.s.l., which is almost near the top of the PBL in summer. Thus, the Mt. Tai data can provide insights into the chemical conditions in the top boundary layer during the day and in the residual layer during the night. Our observations at Mt. Tai demonstrate the serious nitrate aerosol pollution throughout the PBL in the NCP region. Furthermore, the nitrate formation mechanisms, including the major formation routes and sensitivities to $\mathrm{NO}_{x}, \mathrm{O}_{3}$ and $\mathrm{NH}_{3}$, were fairly consistent between Mt. Tai and the surface sites. This implies the regional homogeneity in the in situ formation of fine nitrate aerosol within the PBL over the NCP region. 

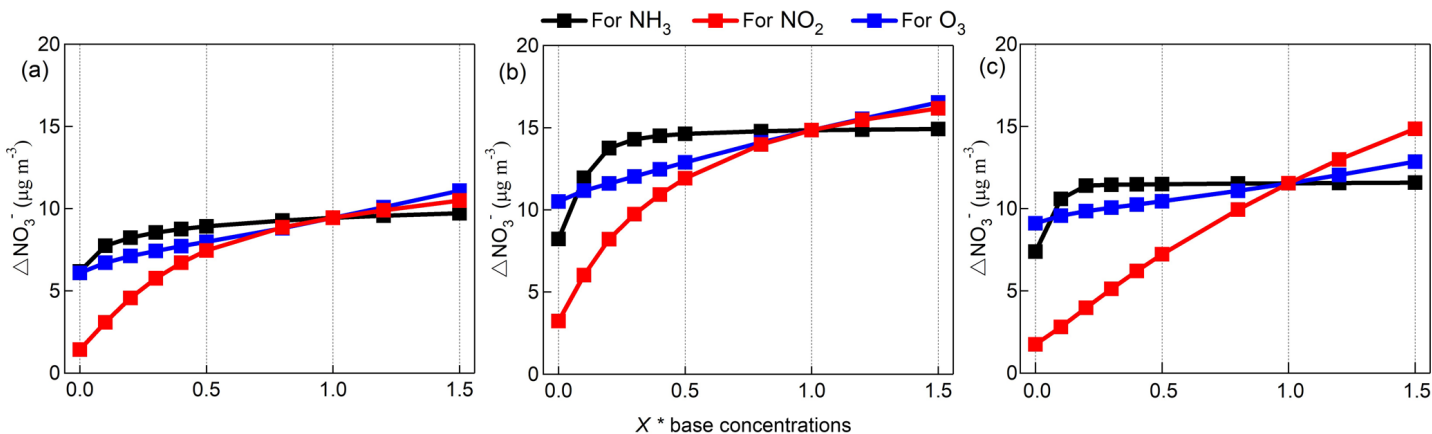

Figure 6. Model-simulated daytime average $\mathrm{NO}_{3}^{-}$enhancements as a function of the $X$ times of the base concentrations of $\mathrm{NH}_{3}, \mathrm{NO}_{2}$ and $\mathrm{O}_{3}$ in (a) urban Jinan, (b) rural Yucheng and (c) Mt. Tai. The results are the average of sensitivity analyses for all selected daytime cases.
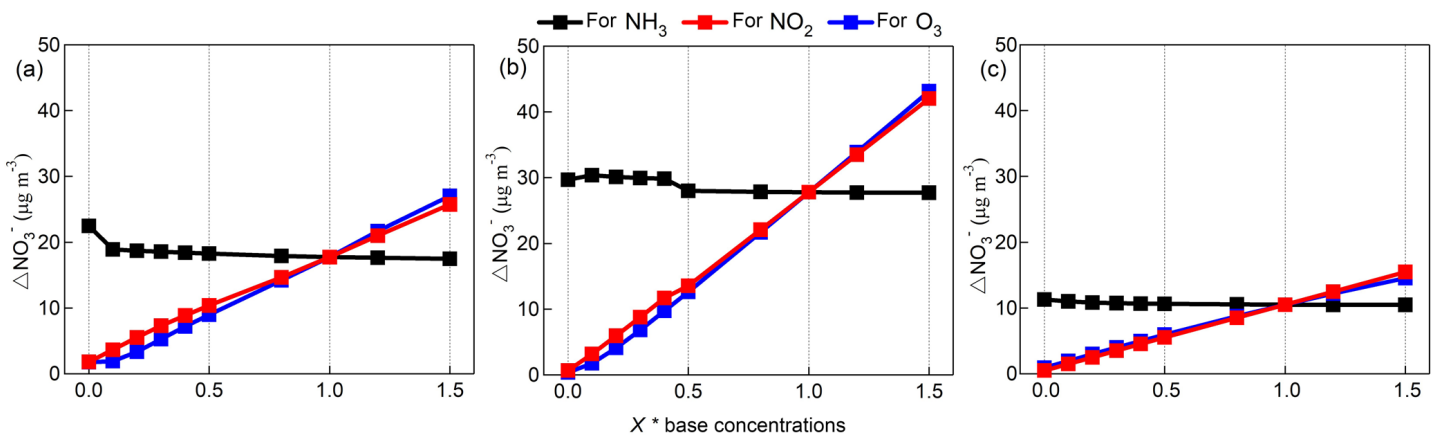

Figure 7. The same as Fig. 6 but for the nocturnal nitrate formation cases.

\subsection{Implications for control policy}

The above analyses revealed the important roles of $\mathrm{NO}_{2}$ and $\mathrm{O}_{3}$ in nitrate formation in three different types of areas. Although $\mathrm{NH}_{3}$ can facilitate the partitioning of $\mathrm{HNO}_{3}$ to the aerosol phase, it seems that the summertime nitrate formation is less sensitive to $\mathrm{NH}_{3}$ due to the $\mathrm{NH}_{3}$-rich environments in the NCP region. To achieve a comprehensive understanding of the effect of $\mathrm{NH}_{3}$ on nitrate formation, a large set of theoretical simulations were designed with varying initial concentrations of $\mathrm{NO}_{2}$ and $\mathrm{NH}_{3}$. The multiphase chemical box model was initialized by a typical pollution and meteorological condition in the NCP region (see Table S5 for the detailed modeling setup) and was run to simulate the daytime nitrate formation from 08:00 to 19:00 LT. The initial concentrations of $\mathrm{NO}_{2}$ and $\mathrm{NH}_{3}$ were set to vary in wide ranges of 0-200 and 0-40 ppbv to cover a variety of real atmospheric conditions. The dependence of the model-simulated nitrate increment $\left(\Delta \mathrm{NO}_{3}^{-}\right)$on the pair of $\mathrm{NO}_{2}$ and $\mathrm{NH}_{3}$ can be established.

Figure 8 shows the contour plot of the model-simulated daytime $\Delta \mathrm{NO}_{3}^{-}$as a function of $\mathrm{NO}_{2}$ and $\mathrm{NH}_{3}$ concentrations. Several interesting aspects are noteworthy from the figure. First, $\mathrm{NH}_{3}$ does indeed play a very important role in prompting nitrate formation. A relatively small amount of $\mathrm{NH}_{3}$ could significantly enhance the nitrate formation ef-

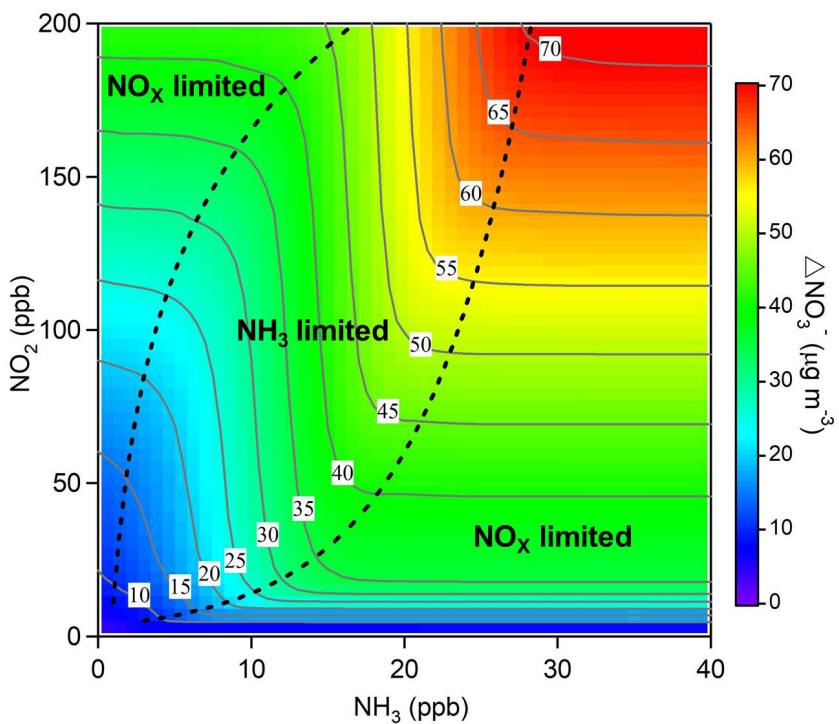

Figure 8. Contour plot of the model-simulated daytime $\mathrm{NO}_{3}^{-}$formation as a function of the initial concentrations of $\mathrm{NO}_{2}(0-$ $200 \mathrm{ppbv})$ and $\mathrm{NH}_{3}(0-40 \mathrm{ppbv})$. Note that the dashed lines are artificially drawn to separate the three zones with a different sensitivity of nitrate formation to $\mathrm{NO}_{2}$ and $\mathrm{NH}_{3}$. 


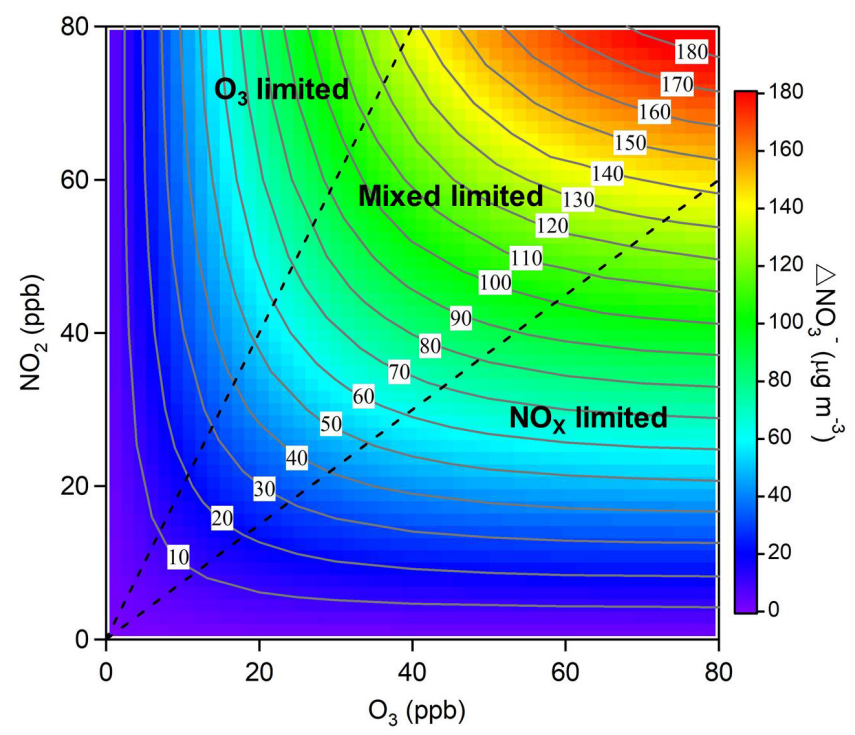

Figure 9. Contour plot of the model-simulated nighttime $\mathrm{NO}_{3}^{-}$ formation as a function of the initial concentrations of $\mathrm{NO}_{2}(0-$ $80 \mathrm{ppbv})$ and $\mathrm{O}_{3}(0-80 \mathrm{ppbv})$. Note that the dashed lines are artificially drawn to separate the three zones with a different sensitivity of nitrate formation to $\mathrm{NO}_{2}$ and $\mathrm{O}_{3}$.

ficiency of $\mathrm{NO}_{x}$. For example, the formation of $25 \mu \mathrm{g} \mathrm{m} \mathrm{m}^{-3}$ of $\mathrm{NO}_{3}^{-}$would consume $116 \mathrm{ppbv}$ of $\mathrm{NO}_{2}$ in the absence of $\mathrm{NH}_{3}$ but only need $16 \mathrm{ppbv}$ of $\mathrm{NO}_{2}$ in the presence of $10 \mathrm{ppbv}$ of $\mathrm{NH}_{3}$. Second, in high $\mathrm{NH}_{3}$ conditions, nitrate formation becomes insensitive to $\mathrm{NH}_{3}$. Nitrate formation is mainly limited by $\mathrm{NO}_{2}$ when $\mathrm{NH}_{3}$ is in excess. Third, the nitrate formation regimes can be divided into three types, namely, " $\mathrm{NO}_{x}$-limited in $\mathrm{NH}_{3}$-deficient conditions", " $\mathrm{NH}_{3}$ controlled" and " $\mathrm{NO}_{x}$-limited in $\mathrm{NH}_{3}$-rich conditions", according to the concentration ratios of $\mathrm{NO}_{2}$ and $\mathrm{NH}_{3}$. The identification of the nitrate formation regime is a fundamental step towards the formulation of a science-based control policy of nitrate pollution.

Similarly, we also performed theoretical simulations to examine the detailed dependence of nocturnal nitrate formation on both $\mathrm{NO}_{2}$ and $\mathrm{O}_{3}$. The detailed model configuration is given in Table S6 in the Supplement. The initial concentrations of $\mathrm{NO}_{2}$ and $\mathrm{O}_{3}$ were set to vary in the range of $0-80 \mathrm{ppbv}$ to represent various nocturnal environments. The contour plot is shown in Fig. 9. It clearly shows the three categories of nighttime nitrate formation regimes, i.e., " $\mathrm{NO}_{x}$-limited" under high $\mathrm{O}_{3}$ and low $\mathrm{NO}_{2}$ conditions, " $\mathrm{O}_{3}$ limited" in low $\mathrm{O}_{3}$ and high $\mathrm{NO}_{2}$ conditions, and "mixedlimited" by both $\mathrm{NO}_{x}$ and $\mathrm{O}_{3}$. The ambient pollution conditions measured at the three study sites in the present study were generally in the mixed-limited regime. Effective control measures could be established based upon the diagnosis of the nitrate formation regimes.

Our findings have important implications for the control policy of regional aerosol pollution. Our observations demonstrate the increasing trend and serious situation of nitrate pollution over the NCP region. Given the decline in sulfate and primary particles in the recent decade (Wang et al., 2013), nitrate should be a major target for the future control of haze pollution in China. The observation-based modeling analyses in this study suggest that the summertime nitrate formation in the NCP region is mainly controlled by $\mathrm{NO}_{x}$ and $\mathrm{O}_{3}$ (particularly in nighttime). Recent studies have also confirmed the increasing trends of surface $\mathrm{O}_{3}$ levels in the past decades in several major fast-developing regions of eastern China (Ding et al., 2008; Xu et al., 2008; T. Wang et al., 2009; Xue et al., 2014; Sun et al., 2016). Therefore, further reduction in anthropogenic $\mathrm{NO}_{x}$ emissions and mitigation of regional $\mathrm{O}_{3}$ pollution should be an efficient way to alleviate the nitrate-driven haze pollution in China. $\mathrm{NH}_{3}$ also plays a very important role in the nitrate aerosol formation, as a relatively small amount could efficiently prompt $\mathrm{HNO}_{3}$-to- $\mathrm{NO}_{3}^{-}$partitioning and nitrate formation. However, the summertime nitrate formation seems to be less sensitive to $\mathrm{NH}_{3}$ in the $\mathrm{NCP}$ region, where ambient $\mathrm{NH}_{3}$ is generally in excess. Indeed, the available field observations of ambient $\mathrm{NH}_{3}$ confirmed the widespread $\mathrm{NH}_{3}$-excess chemical environments in polluted regions of northern China (Meng et al., 2018 and references therein). Thus, it looks like cutting down the $\mathrm{NO}_{x}$ emissions should be more efficient for the current control of nitrate pollution in the $\mathrm{NH}_{3}$-rich environments. Nevertheless, reduction in $\mathrm{NH}_{3}$ emissions is still very important for the future aerosol pollution control in North China from a long-term perspective in light of the fact that nitrate formation would be largely restricted in $\mathrm{NH}_{3}$-poor conditions (see Fig. 8).

It is worth noting that in addition to $\mathrm{NO}_{x}, \mathrm{O}_{3}$ and $\mathrm{NH}_{3}$, there are also some other factors that influence nitrate formation. For example, VOCs are principal $\mathrm{O}_{3}$ precursors, and regulate the abundances of $\mathrm{OH}$ and losses of $\mathrm{NO}_{3}$ (and $\mathrm{N}_{2} \mathrm{O}_{5}$ ). Thus, VOCs can affect the daytime $\mathrm{HNO}_{3}$ formation and nocturnal $\mathrm{N}_{2} \mathrm{O}_{5}$ hydrolysis, which in turn affect nitrate formation. In addition, the increasing nitrate aerosol may reduce the $\mathrm{N}_{2} \mathrm{O}_{5}$ uptake and restrict the nocturnal nitrate formation (Chang et al., 2011). The results in Fig. 9 only hold if the sensitivity of nitrate production to $\mathrm{N}_{2} \mathrm{O}_{5}$ uptake does not change under different $\mathrm{NO}_{x}$ and $\mathrm{O}_{3}$ conditions. Furthermore, the model simulations are constrained to ground-based observations and the chemistry aloft may show a different sensitivity than in Figs. 7 and 9. These aspects were not quantified in this study. Further studies are needed to explore the detailed dependence of nitrate formation on a variety of factors including $\mathrm{NO}_{x}, \mathrm{O}_{3}, \mathrm{NH}_{3}$, VOCs, aerosol composition and meteorological conditions.

\section{Conclusions}

We report recent field measurements of fine particulate nitrate chemistry at an urban, a rural and a remote sites in the 
NCP region. Serious aerosol pollution was observed at all sites, with nitrate accounting for on average $11-14 \%$ of the $\mathrm{PM}_{2.5}$. Distinct temporal and spatial distributions of nitrate pollution were found at different sites. The $\mathrm{NO}_{3}^{-} / \mathrm{PM}_{2.5}$ and $\mathrm{NO}_{3}^{-} / \mathrm{SO}_{4}^{2-}$ ratios have increased significantly in urban Jinan over 2005-2015 and at Mt. Tai from 2007 to 2014, highlighting the worsening situation of nitrate pollution in the region. Fine nitrate aerosol was primarily formed via the production of $\mathrm{HNO}_{3}$ followed by its partitioning to the aerosol phase during the day and by the hydrolysis reactions of $\mathrm{N}_{2} \mathrm{O}_{5}$ on particles during the night. The daytime nitrate formation was mainly controlled by $\mathrm{NO}_{2}$ and to a lesser extent by $\mathrm{O}_{3}$ and $\mathrm{NH}_{3}$, and the nocturnal formation was controlled by both $\mathrm{NO}_{2}$ and $\mathrm{O}_{3} . \mathrm{NH}_{3}$ plays a vital role in nitrate formation by prompting the partitioning of $\mathrm{HNO}_{3}$ to particles. A small amount of $\mathrm{NH}_{3}$ can significantly enhance the efficiency of nitrate formation from $\mathrm{NO}_{x}$. Given the high $\mathrm{NH}_{3}$-excess conditions, the summertime nitrate formation was relatively less sensitive to $\mathrm{NH}_{3}$ in the $\mathrm{NCP}$ region. We recommend that further reduction in anthropogenic emissions of $\mathrm{NO}_{x}$ should be the most efficient pathway for the current control of nitrate aerosol, whilst the control of regional ozone pollution and $\mathrm{NH}_{3}$ emissions is very important for the future haze pollution control in China. Some recent studies have reported a rapid decrease in the $\mathrm{NO}_{x}$ abundances over eastern China since 2011 (Liu et al., 2017). It can be expected that such a reduction in $\mathrm{NO}_{x}$ would help to alleviate the nitrate particulate pollution in China. More observational studies are needed to further examine the trend in nitrate aerosol and assess the contributions of the strict $\mathrm{NO}_{x}$ control in China. We also note that the present study was only confined to summer conditions and the chemical mix of $\mathrm{NO}_{2}, \mathrm{O}_{3}$ and $\mathrm{NH}_{3}$ is likely to be different in wintertime (e.g., higher $\mathrm{NO}_{x}$ levels and relatively low $\mathrm{O}_{3}$ and $\mathrm{NH}_{3}$ concentrations). Further studies are urgently needed to better understand the formation regimes of nitrate aerosol in winter, when the haze pollution is more serious in China.

Data availability. The data used in this study are available from the corresponding author upon request (xuelikun@sdu.edu.cn).

\section{The Supplement related to this article is available online at https://doi.org/10.5194/acp-18-11261-2018- supplement.}

Author contributions. LW conducted the field campaigns; LW and LX analyzed the data and wrote the paper; XW, CX, LY and TC were involved in the field campaigns; TW, QZ and WW were involved in data discussion.

Competing interests. The authors declare that they have no conflict of interest.
Special issue statement. This article is part of the special issue "Regional transport and transformation of air pollution in eastern China". It does not belong to a conference.

Acknowledgements. The authors thank Lan Yao, Yanhong Zhu, Junmei Zhang and Hao Wang for their efforts in the field measurements and thank Hartmut Herrmann for providing the multiphase chemical model. This work was funded by the National Key Research and Development Program of China (no. 2016YFC0200500), the National Natural Science Foundation of China (no. 91544213 and 41505111), the Natural Science Foundation of Shandong Province (ZR2014BQ031), the Qilu Youth Talent Program of Shandong University, the Taishan Scholars (ts201712003) and the Jiangsu Collaborative Innovation Center for Climate Change. We also thank the editor and three anonymous reviewers for their comments which are very helpful for improving the original paper.

Edited by: David Parrish

Reviewed by: three anonymous referees

\section{References}

Achtert, P., Birmili, W., Nowak, A., Wehner, B., Wiedensohler, A., Takegawa, N., Kondo, Y., Miyazaki, Y., Hu, M., and Zhu, T.: Hygroscopic growth of tropospheric particle number size distributions over the North China Plain, J. Geophys. Res., 114, D00G07, https://doi.org/10.1029/2008jd010921, 2009.

Baasandorj, M., Hoch, S. W., Bares, R., Lin, J. C., Brown, S. S., Millet, D. B., Martin, R., Kelly, K., Zarzana, K. J., Whiteman, C. D., Dube, W. P., Tonnesen, G., Jaramillo, I. C., and Sohl, J.: Coupling between Chemical and Meteorological Processes under Persistent Cold-Air Pool Conditions: Evolution of Wintertime $\mathrm{PM}_{2.5}$ Pollution Events and $\mathrm{N}_{2} \mathrm{O}_{5}$ Observations in Utah's Salt Lake Valley, Environ. Sci. Technol., 51, 5941-5950, 2017.

Brink, H. T., Otjes, R., Jongejan, P., and Kos, G.: Monitoring of the ratio of nitrate to sulphate in size-segregated submicron aerosol in the Netherlands, Atmos. Res., 92, 270-276, 2009.

Brown, S. G., Hyslop, N. P., Roberts, P. T., McCarthy, M. C., Lurmann, F. W.: Wintertime vertical variations in particulate matter (PM) and precursor concentrations in the San Joaquin Valley during the California Regional Coarse PM/Fine PM Air Quality Study, J. Air Waste Manag. Assoc., 56, 1267-1277, doi.org/10.1080/10473289.2006.10464583, 2006.

Brown, S. S. and Stutz, J.: Nighttime radical observations and chemistry, Chem. Soc. Rev., 41, 6405-6447, https://doi.org/10.1039/c2cs35181a, 2012.

Calvert, J. G. and Stockwell, W. R.: Acid generation in the troposphere by gas-phase chemistry, Environ. Sci. Technol., 17, 428433, 1983.

Chang, W. L., Bhave, P. V., Brown, S. S., Riemer, N., Stutz, J., and Dabdub, D.: Heterogeneous Atmospheric Chemistry, Ambient Measurements, and Model Calculations of $\mathrm{N}_{2} \mathrm{O}_{5}$ : A Review, Aerosol Sci. Technol., 45, 665-695, https://doi.org/10.1080/02786826.2010.551672, 2011. 
Clegg, S. L., Brimblecombe, P., and Wexler, A. S.: Thermodynamic Model of the System $\mathrm{H}^{+}-\mathrm{NH}_{4}^{+}-\mathrm{Na}^{+}-\mathrm{SO}_{4}^{2-}-\mathrm{NO}_{3}^{-}-\mathrm{Cl}^{-}-\mathrm{H}_{2} \mathrm{O}$ at 298.15 K, J. Phys. Chem., 102, 2155-2171, 1998.

Dentener, F. J. and Crutzen, P. J.: Reaction of $\mathrm{N}_{2} \mathrm{O}_{5}$ on tropospheric aerosols: impact on the global distributions of $\mathrm{NO}_{x}, \mathrm{O}_{3}$, and $\mathrm{OH}$, J. Geophys. Res., 98, 7149-7163, 1993.

Ding, A. J., Wang, T., Thouret, V., Cammas, J.-P., and Nédélec, P.: Tropospheric ozone climatology over Beijing: analysis of aircraft data from the MOZAIC program, Atmos. Chem. Phys., 8, 1-13, https://doi.org/10.5194/acp-8-1-2008, 2008.

Ding, A. J., Fu, C. B., Yang, X. Q., Sun, J. N., Petäjä, T., Kerminen, V. M., Wang, T., Xie, Y., Herrmann, E., Zheng, L. F., Nie, W., Liu, Q., Wei, X. L., and Kulmala, M.: Intense atmospheric pollution modifies weather: a case of mixed biomass burning with fossil fuel combustion pollution in eastern China, Atmos. Chem. Phys., 13, 10545-10554, https://doi.org/10.5194/acp-13-105452013, 2013.

Fukushima, S., Zhang, D., Shibata, T., Katagiri, S., and Hayasaka, T.: Dependence of backscattering coefficients of atmospheric particles on their concentration and constitution under day and humid conditions at Southwestern Japanese coast in spring, Aerosol Air Qual. Res., 16, 1294-1301, 2016.

Gao, J., Wang, T., Ding, A., and Liu, C.: Observational study of ozone and carbon monoxide at the summit of mount Tai (1534 m a.s.1.) in central-eastern China, Atmos. Environ., 39, 4779-4791, 2005.

Gao, X., Yang, L., Cheng, S., Gao, R., Zhou, Y., Xue, L., Shou, Y., Wang, J., Wang, X., Nie, W., Xu, P., and Wang, W.: Semicontinuous measurement of water-soluble ions in $\mathrm{PM}_{2.5}$ in Jinan, China: Temporal variations and source apportionments, Atmos. Environ., 45, 6048-6056, 2011.

Goliff, W. S., Stockwell, W. R., and Lawson, C. V.: The regional atmospheric chemistry mechanism, version 2, Atmos. Environ., 68, 174-185, 2013.

Guo, J., Wang, Y., Shen, X., Wang, Z., Lee, T., Wang, X., Li, P., Sun, M., Collett, J. L., Wang, W., and Wang, T.: Characterization of cloud water chemistry at Mount Tai, China: Seasonal variation, anthropogenic impact, and cloud processing, Atmos. Environ., 60, 467-476, 2012.

Hallquist, M., Wängberg, I., Ljungström, E., Barnes, I., and Becker, K. H.: Aerosol and Product Yields from $\mathrm{NO}_{3}$ Radical-Initiated Oxidation of Selected Monoterpenes, Environ. Sci. Technol., 33, 553-559, 1999.

Hao, J., Wang, S., Liu, B., and He, K.: Designation of acid rain and $\mathrm{SO}_{2}$ control zones and control policies in China, J. Environ. Sci. Hea., 35, 1901-1914, 2000.

Hao, J., He, K., Duan, L., Li, J., and Wang, L.: Air pollution and its control in China, Front. Environ. Sci. Eng. China, 1, 129-142, 2007.

Herrmann, H., Ervens, B., Jacobi, H.-W., Wolke, R., Nowacki, P., and Zellner, R.: CAPRAM2.3: A Chemical Aqueous Phase Radical Mechanism for Tropospheric Chemistry, J. Atmos. Chem., 36, 231-284, 2000.

Herrmann, H., Tilgner, A., Barzaghi, P., Majdik, Z., Gligorovski, S., Poulain, L., and Monod, A.: Towards a more detailed description of tropospheric aqueous phase organic chemistry: CAPRAM 3.0, Atmos. Environ., 39, 4351-4363, 2005.

Huang, R. J., Zhang, Y., Bozzetti, C., Ho, K. F., Cao, J. J., Han, Y., Daellenbach, K. R., Slowik, J. G., Platt, S. M., Canonaco, F., Zot- ter, P., Wolf, R., Pieber, S. M., Bruns, E. A., Crippa, M., Ciarelli, G., Piazzalunga, A., Schwikowski, M., Abbaszade, G., SchnelleKreis, J., Zimmermann, R., An, Z., Szidat, S., Baltensperger, U., El Haddad, I., and Prevot, A. S.: High secondary aerosol contribution to particulate pollution during haze events in China, Nature, 514, 218-222, 2014.

Li, C., McLinden, C., Fioletov, V., Krotkov, N., Carn, S., Joiner, J., Streets, D., He, H., Ren, X., Li, Z., and Dickerson, R. R.: India Is Overtaking China as the World's Largest Emitter of Anthropogenic Sulfur Dioxide, Sci. Rep., 7, 14304, https://doi.org/10.1038/s41598-017-14639-8, 2017.

Li, H., Zhang, Q., Zheng, B., Chen, C., Wu, N., Guo, H., Zhang, Y., Zheng, Y., Li, X., and He, K.: Nitrate-driven urban haze pollution during summertime over the North China Plain, Atmos. Chem. Phys., 18, 5293-5306, https://doi.org/10.5194/acp18-5293-2018, 2018.

Liu, F., Beirle, S., Zhang, Q., van der A, R. J., Zheng, B., Tong, D., and He, K.: $\mathrm{NO}_{x}$ emission trends over Chinese cities estimated from OMI observations during 2005 to 2015, Atmos. Chem. Phys., 17, 9261-9275, https://doi.org/10.5194/acp-179261-2017, 2017.

Liu, X., Zhang, Y., Han, W., Tang, A., Shen, J., Cui, Z., Vitousek, P., Erisman, J. W., Goulding, K., Christie, P., Fangmeier, A., and Zhang, F.: Enhanced nitrogen deposition over China, Nature, 494, 459-462, 2013.

McDuffie, E. E., Fibiger, D. L., Dubé, W. P., Lopez-Hilfiker, F., Lee, B. H., Thornton, J. A., et al.: Heterogeneous $\mathrm{N}_{2} \mathrm{O}_{5}$ uptake during winter: Aircraft measurements during the 2015 WINTER campaign and critical evaluation of current parameterizations. J. Geophys. Res.-Atmos., 123, 4345-4372, https://doi.org/10.1002/2018JD028336, 2018.

Meng, Z., Xu, X., Lin, W., Ge, B., Xie, Y., Song, B., Jia, S., Zhang, R., Peng, W., Wang, Y., Cheng, H., Yang, W., and Zhao, H.: Role of ambient ammonia in particulate ammonium formation at a rural site in the North China Plain, Atmos. Chem. Phys., 18, 167184, https://doi.org/10.5194/acp-18-167-2018, 2018.

Nozaki, K. Y.: Mixing Depth Model Using Hourly Surface Observations, USAF Environmental Technical Applications Center, Report 7053, 1973.

Pathak, R. K., Wu, W. S., and Wang, T.: Summertime $\mathrm{PM}_{2.5}$ ionic species in four major cities of China: nitrate formation in an ammonia-deficient atmosphere, Atmos. Chem. Phys., 9, 17111722, https://doi.org/10.5194/acp-9-1711-2009, 2009.

Pathak, R. K., Wang, T., and Wu, W. S.: Nighttime enhancement of $\mathrm{PM}_{2.5}$ nitrate in ammonia-poor atmospheric conditions in Beijing and Shanghai: Plausible contributions of heterogeneous hydrolysis of $\mathrm{N}_{2} \mathrm{O}_{5}$ and $\mathrm{HNO}_{3}$ partitioning, Atmos. Environ., 45, 1183-1191, 2011.

Prabhakar, G., Parworth, C. L., Zhang, X., Kim, H., Young, D. E., Beyersdorf, A. J., Ziemba, L. D., Nowak, J. B., Bertram, T. H., Faloona, I. C., Zhang, Q., and Cappa, C. D.: Observational assessment of the role of nocturnal residuallayer chemistry in determining daytime surface particulate nitrate concentrations. Atmos. Chem. Phys., 17, 14747-14770. https://doi.org/10.5194/acp-17-14747-2017, 2017.

Pusede, S. E., Duffey, K. C., Shusterman, A. A., Saleh, A., Laughner, J. L., Wooldridge, P. J., Zhang, Q., Parworth, C. L., Kim, H., Capps, S. L., Valin, L. C., Cappa, C. D., Fried, A., Walega, J., Nowak, J. B., Weinheimer, A. J., Hoff, R. M., Berkoff, T. A., 
Beyersdorf, A. J., Olson, J., Crawford, J. H., and Cohen, R. C.: On the effectiveness of nitrogen oxide reductions as a control over ammonium nitrate aerosol, Atmos. Chem. Phys., 16, 25752596, https://doi.org/10.5194/acp-16-2575-2016, 2016.

Roberts, J. M., Osthoff, H. D., Brown, S. S., and Ravishankara, A. R.: $\mathrm{N}_{2} \mathrm{O}_{5}$ oxidizes chloride to $\mathrm{Cl}_{2}$ in acidic atmospheric aerosol. Science, 321, p. 1059, https://doi.org/10.1126/science.1158777, 2008.

Schwartz, S. E.: Mass-Transport Considerations Pertinent to Aqueous Phase Reactions of Gases in Liquid-Water Clouds, Chem. Mul. Atmos. Sys., 6, 415-471, 1986.

Shen, X., Lee, T., Guo, J., Wang, X., Li, P., Xu, P., Wang, Y., Ren, Y., Wang, W., Wang, T., Li, Y., Carn, S. A., and Collett, J. L.: Aqueous phase sulfate production in clouds in eastern China, Atmos. Environ., 62, 502-511, 2012.

Song, C. H. and Carmichael, G. R.: Gas-particle partitioning of nitric acid modulated by alkaline aerosol, J. Atmos. Chem., 40, 1-22, 2001.

Sun, L., Xue, L., Wang, T., Gao, J., Ding, A., Cooper, O. R., Lin, M., Xu, P., Wang, Z., Wang, X., Wen, L., Zhu, Y., Chen, T., Yang, L., Wang, Y., Chen, J., and Wang, W.: Significant increase of summertime ozone at Mount Tai in Central Eastern China, Atmos. Chem. Phys., 16, 10637-10650, https://doi.org/10.5194/acp-1610637-2016, 2016.

Tham, Y. J., Wang, Z., Li, Q., Wang, W., Wang, X., Lu, K., Ma, N., Yan, C., Kecorius, S., Wiedensohler, A., Zhang, Y., and Wang, T.: Heterogeneous $\mathrm{N}_{2} \mathrm{O}_{5}$ uptake coefficient and production yield of $\mathrm{ClNO}_{2}$ in polluted northern China: Roles of aerosol water content and chemical composition, Atmos. Chem. Phys. Discuss., https://doi.org/10.5194/acp-2018-313, in review, 2018.

Wang, H., Lu, K., Chen, X., Zhu, Q., Chen, Q., Guo, S., Jiang, M., Li, X., Shang, D., Tan, Z., Wu, Y., Wu, Z., Zou, Q., Zheng, Y., Zeng, L., Zhu, T., Hu, M., and Zhang, Y.: High $\mathrm{N}_{2} \mathrm{O}_{5}$ concentrations observed in urban Beijing: implications of a large nitrate formation pathway, Environ. Sci. Tech., 4, 416-420, 2017.

Wang, L. W., Wen, L., Xu, C. H., Chen, J. M., Wang, X. F., Yang, L. X., Wang, W. X., Yang, X., Sui, X., Yao, L., and Zhang, Q. Z.: HONO and its potential source particulate nitrite at an urban site ni North CHina during the cold season, Sci. Total Environ., 538, 93-101, 2015.

Wang, N., Li, N., Liu, Z., and Evans, E.: Investigation of chemical reactivity and active comp-onents of ambient VOCs in Jinan, China, Air Quality, Atmos. Health, 9, 785-793, 2015.

Wang, T., Wei, X. L., Ding, A. J., Poon, C. N., Lam, K. S., Li, Y. S., Chan, L. Y., and Anson, M.: Increasing surface ozone concentrations in the background atmosphere of Southern China, 1994-2007, Atmos. Chem. Phys., 9, 6217-6227, https://doi.org/10.5194/acp-9-6217-2009, 2009.

Wang, X., Zhang, Y., Chen, H., Yang, X., and Chen, J.: Particulate Nitrate Formation in a Highly Polluted Urban Area A Case Study by Single-Particle Mass Spectrometry in Shanghai, Environ. Sci. Technol., 43, 3061-3066, 2009.

Wang, Y., Zhang, Q. Q., He, K., Zhang, Q., and Chai, L.: Sulfate-nitrate-ammonium aerosols over China: response to 2000-2015 emission changes of sulfur dioxide, nitrogen oxides, and ammonia, Atmos. Chem. Phys., 13, 2635-2652, https://doi.org/10.5194/acp-13-2635-2013, 2013.

Wang, Z., Wang, T., Guo, J., Gao, R., Xue, L., Zhang, J., Zhou, Y., Zhou, X., Zhang, Q., and Wang, W.: Formation of secondary organic carbon and cloud impact on carbonaceous aerosols at Mount Tai, North China, Atmos. Environ., 46, 516-527, 2012.

Wang, Z., Wang, W., Tham, Y. J., Li, Q., Wang, H., Wen, L., Wang, X., and Wang, T.: Fast heterogeneous $\mathrm{N}_{2} \mathrm{O}_{5}$ uptake and $\mathrm{ClNO}_{2}$ production in power plant and industrial plumes observed in the nocturnal residual layer over the North China Plain, Atmos. Chem. Phys., 17, 12361-12378, https://doi.org/10.5194/acp-1712361-2017, 2017.

Watson, J. G. and Chow, J. C.: A wintertime PM 2.5 episode at the Fresno, CA, supersite. Atmos. Environ., 36, 465-475, https://doi.org/10.1016/S1352-2310(01)00309-0, 2002.

Wen, L., Chen, J., Yang, L., Wang, X., Xu, C., Sui, X., Yao, L., Zhu, Y., Zhang, J., Zhu, T., and Wang, W.: Enhanced formation of fine particulate nitrate at a rural site on the North China Plain in summer: The important roles of ammonia and ozone, Atmos. Environ., 101, 294-302, 2015.

Xie, Y., Ding, A., Nie, W., Mao, H., Qi, X., Huang, X., Xu, Z., Kerminen, V.-M., Petäjä, T., Chi, X., Virkkula, A., Boy, M., Xue, L., Guo, J., Sun, J., Yang, X., Kulmala, M., and Fu, C.: Enhanced sulfate formation by nitrogen dioxide: Implications from in situ observations at the SORPES station, J. Geophys. Res., 120, 12679-12694, 10.1002/2015JD02360, 2015.

Xie, Y., Dai, H., Dong, H., Hanaoka, T., and Masui, T.: Economic Impacts from $\mathrm{PM}_{2.5}$ Pollution-Related Health Effects in China: A Provincial-Level Analysis, Environ. Sci. Technol., 50, 48364843, 2016.

$\mathrm{Xu}$, L. and Penner, J. E.: Global simulations of nitrate and ammonium aerosols and their radiative effects, Atmos. Chem. Phys., 12, 9479-9504, https://doi.org/10.5194/acp-12-94792012, 2012.

Xu, X., Lin, W., Wang, T., Yan, P., Tang, J., Meng, Z., and Wang, Y.: Long-term trend of surface ozone at a regional background station in eastern China 1991-2006: enhanced variability, Atmos. Chem. Phys., 8, 2595-2607, https://doi.org/10.5194/acp-8-25952008, 2008.

Xue, L. K., Wang, T., Gao, J., Ding, A. J., Zhou, X. H., Blake, D. R., Wang, X. F., Saunders, S. M., Fan, S. J., Zuo, H. C., Zhang, Q. Z., and Wang, W. X.: Ground-level ozone in four Chinese cities: precursors, regional transport and heterogeneous processes, Atmos. Chem. Phys., 14, 13175-13188, dpo:10.5194/acp-14-13175-2014, 2014.

Yang, L., Zhou, X., Wang, Z., Zhou, Y., Cheng, S., Xu, P., Gao, X., Nie, W., Wang, X., and Wang, W.: Airborne fine particulate pollution in Jinan, China: Concentrations, chemical compositions and influence on visibility impairment, Atmos. Environ., 55, 506-514, 2012.

Yang, L. X., Wang, D. C., Cheng, S. H., Wang, Z., Zhou, Y., Zhou, X. H., and Wang, W. X.: Influence of meteorological conditions and particulate matter on visual range impairment in Jinan, China, Sci. Total. Environ., 383, 164-173, 2007.

Yao, X. H. and Zhang, L.: Supermicron modes of ammonium ions related to fog in rural atmosphere, Atmos. Chem. Phys., 12, 11165-11178, https://doi.org/10.5194/acp-12-11165-2012, 2012.

Zhang, Y., Seigneur, C., Seinfeld, J. H., Jacobson, M., Clegg, S. L., and Binkowski, F. S.: A comparative review of inorganic aerosol thermodynamic equilibrium modules: similarities, differences, and their likely causes, Atmos. Environ., 34, 117-137, 2000. 
Zhou, Y., Wang, T., Gao, X., Xue, L., Wang, X., Wang, Z., Gao, J., Zhang, Q., and Wang, W.: Continuous observations of watersoluble ions in $\mathrm{PM}_{2.5}$ at Mount Tai (1534 ma.s.1.) in centraleastern China, J. Atmos. Chem., 64, 107-127, 2010.

Zhu, Y., Yang, L., Meng, C., Yuan, Q., Yan, C., Dong, C., Sui, X., Yao, L., Yang, F., Lu, Y., and Wang, W.: Indoor/outdoor relationships and diurnal/nocturnal variations in water-soluble ion and $\mathrm{PAH}$ concentrations in the atmospheric $\mathrm{PM}_{2.5}$ of a business office area in Jinan, a heavily polluted city in China, Atmos. Res., 153, 276-285, 2015.
Zhu, Y., Yang, L., Chen, J., Wang, X., Xue, L., Sui, X., Wen, L., Xu, C., Yao, L., Zhang, J., Shao, M., Lu, S., and Wang, W.: Characteristics of ambient volatile organic compounds and the influence of biomass burning at a rural site in Northern China during summer 2013, Atmos. Environ., 124, 156-165, 2016.

Zhu, Y., Yang, L., Kawamura, K., Chen, J., Ono, K., Wang, X., Xue, L., and Wang, W.: Contributions and source identification of biogenic and anthropogenic hydrocarbons to secondary organic aerosols at Mt. Tai in 2014, Environ. Pollut., 220, 863-872, 2017. 